\title{
Hypocotyl adventitious root organogenesis differs from lateral root development
}

\author{
Inge Verstraeten ${ }^{\dagger}$, Sébastien Schotte and Danny Geelen* \\ Department of Plant Production, Faculty of Bioscience Engineering, Ghent University, Ghent, Belgium
}

\section{Edited by: \\ José Manuel Pérez-Pérez, \\ Universidad Miguel Hernandez de \\ Elche, Spain}

\section{Reviewed by:}

Gloria Muday, Wake Forest University, USA

Laurent Gutierrez, University of Picardie Jules Verne Amiens, France

\section{${ }^{*}$ Correspondence:}

Danny Geelen, Department of Plant Production, Faculty of Bioscience Engineering, Ghent University, Coupure Links 653, B-9000 Ghent Belgium

e-mail: danny.geelen@ugent.be

\section{${ }^{\dagger}$ Present address:}

Inge Verstraeten, Botany and Plant Sciences, University of California at Riverside, Genomics Building, 900 University Avenue, Riverside, CA 92521, USA

\begin{abstract}
Wound-induced adventitious root (AR) formation is a requirement for plant survival upon root damage inflicted by pathogen attack, but also during the regeneration of plant stem cuttings for clonal propagation of elite plant varieties. Yet, adventitious rooting also takes place without wounding. This happens for example in etiolated Arabidopsis thaliana hypocotyls, in which AR initiate upon de-etiolation or in tomato seedlings, in which AR initiate upon flooding or high water availability. In the hypocotyl AR originate from a cell layer reminiscent to the pericycle in the primary root (PR) and the initiated $A R$ share histological and developmental characteristics with lateral roots (LRs). In contrast to the PR however, the hypocotyl is a determinate structure with an established final number of cells. This points to differences between the induction of hypocotyl AR and $L R$ on the PR, as the latter grows indeterminately. The induction of AR on the hypocotyl takes place in environmental conditions that differ from those that control LR formation. Hence, AR formation depends on differentially regulated gene products. Similarly to AR induction in stem cuttings, the capacity to induce hypocotyl AR is genotype-dependent and the plant growth regulator auxin is a key regulator controlling the rooting response. The hormones cytokinins, ethylene, jasmonic acid, and strigolactones in general reduce the root-inducing capacity. The involvement of this many regulators indicates that a tight control and fine-tuning of the initiation and emergence of AR exists. Recently, several genetic factors, specific to hypocotyl adventitious rooting in $A$. thaliana, have been uncovered. These factors reveal a dedicated signaling network that drives AR formation in the Arabidopsis hypocotyl. Here we provide an overview of the environmental and genetic factors controlling hypocotyl-born AR and we summarize how AR formation and the regulating factors of this organogenesis are distinct from LR induction.
\end{abstract}

Keywords: adventitious root, lateral root, differential regulation, plant growth regulators, Arabidopsis thaliana

\section{INTRODUCTION}

Plant roots, hidden below the soil surface, are generally overlooked when one thinks about plant growth and development (Smith and De Smet, 2012). Roots however, are vital for plant growth and function in the uptake of water and nutrients and anchor the plant in its environment (Petricka etal., 2012). The blue print for the primary root (PR) is established during embryogenesis (Scheres et al., 1994), but most root organs are formed post-embryonically. This enables a plant to shape the root architecture in accordance to its needs and the physical constraints imposed by its environment (Hodge et al., 2009; Den Herder etal., 2010; Lynch and Brown, 2012; Lavenus et al., 2013). Monitoring environmental conditions and subsequent translation into signaling processes is key to develop a welladapted root system (Rymen and Sugimoto, 2012). Due to the importance of roots to ensure crop yield under suboptimal water-availability or low soil fertility, the plant's root system is an important target trait to improve crop performance (Lynch, 2007; Kell, 2011; Jung and McCouch, 2013). It therefore is relevant to acquire further insights into root formation, root architecture and the controlling physiological and genetic factors.
The plasticity of the plant's morphology results in a variable root entity, consisting of different root-types organized in a varying spatial configuration. In general, the root system is comprised of at least two root-types: the PR, which is formed during embryogenesis, and post-embryonically initiated lateral roots (LRs) branching of the PR (Celenza etal., 1995). In addition to LR, plants can develop adventitious roots (ARs), which emerge from non-root tissues, such as stems and leaves (Geiss et al., 2009). Some plant species spontaneously develop AR during vegetative reproduction. In other species, AR are specialized organs with specific properties, for example air supply, which is the case for pneumatophoric AR in epiphytic orchids, or support, which occurs in ivy or in stilt roots in mangroves. Moreover, the crown roots, a specific type of AR initiating on predestined nodes in the stems of monocotyledonous plants (e.g., rice and corn), constitute the main roots of monocot root systems (Hochholdinger et al., 2004; Osmont et al., 2007; Bellini et al., 2014). Despite the potential access to unlimited resources via undetermined root growth, plants have limited endogenous energy reserves. Therefore, a strict control of their investment in either primary or secondary roots is necessary. This implicates the existence of a tight regulation of 
different hormonal signaling pathways and factors regulating root development.

The flexible adaptation of the root system to heterogeneous soil environments, the response to nutrients or water availability and the complex hormonal control of root organogenesis provide significant scientific challenges (Monshausen and Gilroy, 2009). Additionally, the variable constitution of a plant's root system, with a complex mix of different root-types complicates the deciphering of the importance of each individual root-type. Research in a model species could aid the root-type-specific analysis. Therefore, a series of studies in the model plant Arabidopsis thaliana has been undertaken (Casson and Lindsey, 2003; Lavenus et al., 2013). Much attention has been given to the development of the PR and to LR initiation, largely because of the amenability of the Arabidopsis root system to microscopic observation and genetic dissection (Beeckman et al., 2001; Casimiro et al., 2001, 2003; Himanen et al., 2002, 2004; De Smet et al., 2006a; Péret et al., 2009a,b; Lavenus et al., 2013). However, etiolated seedlings of this species also develop AR on the elongated hypocotyl and auxin treatments of inflorescence stem segments or leaves result in AR development (Ludwig-Müller et al., 2005; da Rocha Corrêa et al., 2012a,b; da Costa et al., 2013; Verstraeten et al., 2013). Moreover also in light grown seedlings, without an elongated hypocotyl, AR are initiated on the hypocotyl upon excision of the PR (Sukumar et al., 2013). The spontaneous and induced formation of AR in A. thaliana demonstrates that AR are an integral part of the root system. The phenomenon of AR induction can therefore successfully be studied in this species. In addition to Arabidopsis, other species such as tomato, mung bean, pine and sunflower, develop AR on the hypocotyl and have been used in research. In this review we focus on recently acquired knowledge about AR formation and the different regulating factors of primary and secondary root development. In this respect, the hypocotyl is our tissue of interest as it shares similarities, such as the presence of a meristematic pericycle cell layer, which gives rise to LR or $\mathrm{AR}$, and differences to the $\mathrm{PR}$, such as the signaling process leading to AR initiation which differs from the processes leading to LR development. We provide an overview of the environmental, physiological and genetic determinants for the diverse root-types and we summarize how their organogenesis is fundamentally different.

\section{DIFFERENT ROOT-TYPES IN Arabidopsis thaliana PRIMARY ROOT}

The basic feature of a polar plant body, with an aerial part and a PR is already present in the embryo. Upon germination, the PR emerges from the seed and grows gravitropically into the soil by cellular divisions in the apical meristem and subsequent cell elongation (Beemster and Baskin, 1998). The existence of a meristematic center at the root tip is of importance to maintain the root growth. This meristem acts as a growth-organizing center and consists of quiescent cells (QCs), which remain undifferentiated, surrounded by initial cells. These initials differentiate to specific cell types upon asymmetrical divisions (Dolan et al., 1993; Sabatini et al., 2003; Garay-Arroyo et al., 2012). The coordinated divisions of the initial cells lead to a radial pattern of concentric cell layers, each with specific functions (Scheres et al., 2002). Due to the radial organization and the generation of new cells by divisions at the tip, followed by cell elongation and differentiation, spatio-temporal transcript maps of each root cell type are generated (Birnbaum et al., 2003). Some of the key molecular regulators of the PR meristem, such as PLT1 (PLETHORA1), SCR (SCARECROW), and SHR (SHORT ROOT) are also involved in the maintenance of the LR stem cell niche, and most likely also in the AR meristem (Lucas et al., 2010; Della Rovere et al., 2013; Tian et al., 2014). We therefore don't discuss these factors in this review.

Endogenous auxin accumulates in the root tip where it coordinates cell divisions, cell expansion and contributes to the gravitropic response of the root (Sabatini et al., 1999; Petersson et al., 2009; Overvoorde et al., 2010). High levels of auxin stimulate cell division, whereas reduced levels mainly stimulate elongation (Perrot-Rechenmann, 2010). Besides the concentration, also the auxin-type is important to determine cell fate. For example, exogenous 1-naphthaleneacetic acid stimulates cell elongation, while 2,4-dichlorophenoxyacetic acid induces divisions (Campanoni and Nick, 2005). Other plant growth regulators also affect PR growth. Cytokinins for example, determine the rate of cell divisions in the PR meristem, potentially via a redistribution of auxin (Dello Ioio et al., 2007; Chapman and Estelle, 2009; Růžička et al., 2009; Ubeda-Tomás et al., 2012; Della Rovere et al., 2013; Zhang et al., 2013). Abscisic acid (ABA) on the other hand, inhibits cell cycle progression (Wang et al., 1998). Gibberellins (GAs) control the transition to cell elongation (Achard et al., 2009; Ubeda-Tomás etal., 2009). Moreover, hormone actions in the PR often depend on the interaction with auxin biosynthesis and transport (Mähönen et al., 2006; Růžička et al., 2007; Swarup et al., 2007; Bishopp et al., 2011a,b; Liu et al., 2014). It can therefore be concluded that different plant hormone signaling pathways converge at the control of cell divisions in the meristem and cell elongation in higher root zones, dependent or independent of auxin signaling, and thus affect PR growth (Ubeda-Tomás et al., 2012).

\section{LATERAL ROOTS}

Lateral roots emerge post-embryonically from the PR and allow a plant to fully exploit the soil environment (Nibau et al., 2008). LR develop from three files of pericycle cells at the xylem pole (Beeckman et al., 2001; Casimiro et al., 2003). In these xylem pole founder cells, the cell cycle is re-activated and a lateral root primordium (LRP) initiates (De Smet, 2012). Priming of the founder cells takes place in the basal meristem, where oscillating auxin fluxes specify the cell fate (De Smet et al., 2007; Moreno-Risueno et al., 2010; Laskowski, 2013; Van Norman et al., 2013). Following priming, the cells undergo two asymmetric divisions that lead to a single-layered LRP. Subsequent periclinal divisions result in a dome-shaped LRP, which eventually emerges from the parental PR (Himanen et al., 2002; Benková and Bielach, 2010; Dastidar et al., 2012; Smith and De Smet, 2012). LR emergence is controlled by additional signaling factors, auxin import and export. Auxin transport affects both the patterning of the de novo formed LRP and of the cell layers overlaying the LRP to facilitate emergence (Swarup et al., 2008; Péret et al., 2009a, 2012, 2013). 
Under normal growth conditions, LR initiation occurs acropetally, alternating along the PR. This positioning is determined by the auxin oscillation patterns in the basal meristem. Generally, there are more primed pericycle cells than LRP or LR initiated. This allows additional factors to regulate the position of a newly formed root branch. Both nutrients and internal factors, e.g., nitrate and sucrose affect LR formation and shape the root architecture (Malamy and Ryan, 2001; Malamy, 2005; Nibau et al., 2008; Petricka et al., 2012; Roycewicz and Malamy, 2012). Physical stimuli, such as mechanical obstruction and tropic responses also affect the spacing of LR (Richter et al., 2009; Lucas et al., 2013).

Lateral root formation is regulated by a complex interplay of molecular factors and different plant growth regulators (Nibau et al., 2008). Auxin-signaling has an important role from pericycle priming, initiation of cell division, and LRP formation to LR emergence (De Smet, 2012). In contrast to auxin, cytokinin inhibits LR development via a disruption of the patterning in de novo formed LRP and indirectly via an effect on polar auxin transport (Laplaze et al., 2007; Osmont et al., 2007; Rủžička et al., 2009; Bielach et al., 2012). ABA acts as an auxin antagonist during LR initiation (Signora et al., 2001; De Smet et al., 2003; Fukaki and Tasaka, 2009; Guo et al., 2009). Besides the direct role in LR initiation, ABA mediates the balance between cytokinin and auxin and thus also indirectly inhibits LR formation (Shkolnik-Inbar and Bar-Zvi, 2010; Guo et al., 2012). Ethylene mediates auxin responses to inhibit LR formation (Rủžička et al., 2007; Vandenbussche and Van Der Straeten, 2007; Negi et al., 2008, 2010; Lewis et al., 2011; Muday et al., 2012). Other hormones, such as GA, brassinosteroids, and strigolactones potentially act during LR formation via interference with auxin transport and sensitivity (Bao et al., 2004; Koltai et al., 2010; Kapulnik et al., 2011; Ruyter-Spira et al., 2011).

\section{ADVENTITIOUS ROOTS}

Adventitious roots or shoot-borne roots, are roots that develop from non-root tissue, mostly aerial plant parts such as hypocotyls, leaves and stems. Developing adventitious root primordia (ARP) emerge from undifferentiated callus or from reprogrammed cells. Hence, the cellular origin of AR is uncertain and different tissues, often associated with the vasculature or cambial layers, are proposed to generate AR founder cells (Haissig, 1974; Davis and Haissig, 1994; Naija et al., 2008; Bellini et al., 2014). To gain insight into the cellular requirements for AR induction, several Arabidopsis explants have been used to analyze rooting: excised leaves, derooted plants, etiolated seedlings, light-grown seedlings, thin cell layers, and stem segments (Falasca and Altamura, 2003; Falasca et al., 2004; Ludwig-Müller et al., 2005; Fattorini et al., 2009; da Rocha Corrêa et al., 2012a,b; Sukumar et al., 2013; Verstraeten et al., 2013; Welander et al., 2014). In the Arabidopsis hypocotyl, $\mathrm{AR}$ originate from a cell layer reminiscent to the pericycle in the PR and therefore AR may share developmental characteristics with LR (Falasca and Altamura, 2003; Sorin et al., 2006; Li et al., 2009). In contrast to the stem-based Arabidopsis assays (Ludwig-Müller etal., 2005; Verstraeten etal., 2013; Welander et al., 2014), AR form spontaneously on etiolated hypocotyls upon transfer to light (Sorin et al., 2005). Even though AR induction on the hypocotyl does not require exogenous auxin or wounding, both factors enhance AR formation. For example, AR initiate on the hypocotyl of light-grown seedlings from which the PR is excised (Sukumar et al., 2013). In this latter system, wounding acts as the external trigger for de novo ARP formation. The availability of the two Arabidopsis hypocotyl systems allows future comparisons to decipher the role of wounding as a requirement to initiate AR.

Adventitious root formation is a complex process, influenced by multiple factors, including phytohormones, light, wounding, and stress. Auxin plays a central role (De Klerk et al., 1999; Pop et al., 2011) and cytokinin acts as an auxin antagonist (Kuroha and Satoh, 2007; Della Rovere et al., 2013). However, other plant growth regulators, such as ethylene, jasmonic acid, and strigolactones have specific effects on AR and will be discussed below.

\section{KEY ROLE OF AUXIN IN ROOT INDUCTION AND DEVELOPMENT}

Auxin is important for many aspects of root development, including initiation and emergence, patterning of apical meristem, gravitropism, and root elongation. Auxin plays a key role in both AR and LR development (De Klerk et al., 1999; Overvoorde etal., 2010; Pop etal., 2011; Lavenus et al., 2013; Bellini et al., 2014). Mutants or treatments resulting in disturbed polar auxin transport show rooting defects, both in LR and AR formation (Reed et al., 1998; Bhalerao etal., 2002; Himanen et al., 2002; Li etal., 2012; Sukumar et al., 2013). While auxins and auxin signaling are essential for all stages of LR development (Péret et al., 2009a, 2013; Dastidar et al., 2012; Lavenus et al., 2013), exogenous auxin is only stimulating during the first stages of $\mathrm{AR}$ development and inhibits later developmental stages (De Klerk et al., 1995, 1999; Bellamine et al., 1998). This indicates that both root-types have a different sensitivity to exogenous auxin. Besides exogenous or newly biosynthesized auxin, auxin transport, in particular via the ABC-type multi-drug-resistance ABCB19 transporter, is also essential for AR induction in hypocotyls (Sukumar et al., 2013). The release of auxin from storage forms such as indole-3-butyric acid (IBA) or IAA-conjugates also contributes to organ formation. In recent studies using a synthetic auxin analog naxillin, root cap specific IBA-conversion was shown to control priming of pericycle cells and to determine the positioning of LR (De Rybel et al., 2012; Schlicht et al., 2013). Since both AR and LR development depend on auxin signaling factors, exogenous auxin application does not allow root-type specific research.

\section{MOLECULAR FACTORS INVOLVED IN THE INITIATION OF AR IN THE HYPOCOTYL VERSUS LR FORMATION IN THE PR}

Lateral root organogenesis depends on auxin signaling and dominant mutants of the solitary root SLR/IAA14 signal transduction factor lead to omission of cell divisions in the pericycle and aborted LR formation (Fukaki et al., 2002; Vanneste et al., 2005). This indicates a direct link between auxin signaling and formative cell divisions. LR initiation starts with a unique process called priming, which determines the pericycle cells that engage to form LR (Van Norman et al., 2013). Priming is only possible in 
tip-growing organs like roots, where events at the tip determine later responses of the continuously developing cell lines so that the root can adapt to its environment. Priming is mainly controlled by IAA28, with IAA8 and IAA19 in a redundant role. Priming takes place in the basal meristem, where oscillating auxin fluxes specify LR founder cells in the pericycle (De Smet et al., 2007; Moreno-Risueno et al., 2010). Downstream of IAA28 the priming events are controlled by ARF5, 6, 8, and 19 (Lavenus et al., 2013). An additional auxin response factor, ARF7, shows an oscillating expression pattern in the pericycle, which suggest interaction between IAA28 and ARF7 A recently identified GATA-type transcription factor, GATA23, is specifically expressed in the primed pericycle cells, even before the occurrence of asymmetric divisions (De Rybel et al., 2010; Yadav et al., 2010; Dastidar et al., 2012). GATA23-expression depends on IAA28, ARF7, and ARF19 (De Rybel et al., 2010; Yadav et al., 2010). ARF6-ARF8-mediated signaling with GATA23 as a target, specifies LR founder cell (Lavenus et al., 2013). After the priming, asymmetric divisions generate de novo LRP. These asymmetric divisions are controlled by Arabidopsis crinkly 4 (ACR4; De Smet et al., 2008). During the subsequent events in LR development, SLR/IAA14, ARF7 and ARF19 interact, and the Lateral Organ Boundaries-domain/Asymmetric Leaves2-like (LBD/ASL) family positively regulates LR formation in an auxin dependent way (Okushima et al., 2007). Downstream of the SLR/ARF7,19 signaling module, SHY2/IAA3 regulates further LR development (Goh et al., 2012a,b; Lavenus et al., 2013). Via PIN-mediated auxin transport, auxin accumulates at the tip of a developing primordium. This results in the activation of genes necessary for de novo LRP patterning (Péret et al., 2009a). Auxin also affects the cells overlaying the LRP to facilitate emergence. The auxin-import carrier LAX3 regulates the expression of cell wall remodeling enzymes in the outer root tissues and auxin induces aquaporins to facilitate root emergence (Péret et al., 2009a, 2012). In general, at all different stages of LR development, different auxin signaling components play important roles and determine organogenic responses. Recently cell to cell communication via CLE-peptides or ACR4 is shown to be involved in LR organogenesis and programming of the LRP neighboring cells (Stahl and Simon, 2012; Delay etal., 2013; Fernandez etal., 2013; Yue and Beeckman, 2014).

In the Arabidopsis hypocotyl, AR develop from the pericycle (Boerjan etal., 1995; Sorin et al., 2005). In this cell layer, there are so far, no evidence for priming events. The cell number of a hypocotyl is fixed during embryogenesis and no further cell divisions occur during hypocotyl growth. Instead, hypocotyls show a determinate growth pattern with most of their expansions resulting from cell elongation (Gendreau et al., 1997). This is in contrast to the indeterminately growing PR, which has the capacity to determine new sites for LRP formation while it extends into the environment. The final length of the hypocotyl mainly depends on environmental factors such as light and hormones, including auxin, GA, and brassinosteroids (Jensen etal., 1998; Cowling and Harberd, 1999; De Grauwe et al., 2005; Vandenbussche et al., 2005; Chapman et al., 2012). As most hypocotyls cells are present already in the embryo stage, AR priming likely depends on environmental factors. In this context it is of interest to analyze specific molecular markers associated with LR-priming in hypocotyls exposed to different growth conditions.

Similar to LR development, AR development is controlled by auxin-dependent signaling processes. In the hypocotyl, SLR/IAA14 also acts as a factor determining root formation capacity and in slr mutants, no ARP get formed (Fukaki et al., 2002). In the intact hypocotyl, light-induction is necessary to induce AR. This process is mediated by LONG HYPOCOTYL (HY5) and argonaute 1 (Sorin et al., 2005, 2006; Sibout et al., 2006). Proteomic analysis in hypocotyls of the AR-defective ago 1 mutant showed that auxin-conjugate levels are reduced and that AUXIN RESPONSE FACTOR 17 (ARF17) is overexpressed. This suggests $A R F 17$ has a negative role during AR formation (Sorin et al., 2005, 2006). Additionally, auxin-inducible Gretchen Hagen 3-like proteins: GH3-3, GH3-5, and GH3-6 fulfill a role in the fine-tuning of AR initiation via de modulation of jasmonate-homeostasis (Gutierrez et al., 2012). Because ARF17 is a target of miRNA160, a selection of other $A R F$ s regulated by miRNAs were investigated and AR numbers were recorded in ARF6, 8, 10, and 16 mutants. Arf6-3 and arf81 developed less AR, which indicates that ARF6 and ARF8 act as positive regulators of AR formation. ARF6, $A R F 8$, and $A R F 17$ have overlapping expression profiles and regulate each other's transcription level. Moreover, the balance between repressing (ARF17) and activating ( $A R F 6$ and $A R F 8$ ) factors is post-transcriptionally regulated by miR160 and miR167 (Gutierrez et al., 2009). The regulation of JA-homeostasis by GH3 enzymes is sufficient to reduce active jasmonate (JA), an inhibitor of adventitious rooting, and to induce AR (Gutierrez et al., 2012).

The common role of SLR/IAA14 and the identification of similar signal transduction factors (ARF6, ARF8) indicates similarities between the auxin-mediated signaling pathway controlling AR development and the LR induction pathway. Moreover, gh3 mutants are not specific to AR processes only and show small enhancement of LR formation because the enzymes they encode are also involved in auxin homeostasis (Staswick et al., 2005; Zhang et al., 2007; Gutierrez et al., 2012). Other genes, such as LRP1 are expressed in both LRP and ARP and do hence not differentiate between root-types (Smith and Fedoroff, 1995). On the other hand, ARF17 and AGO1 are uniquely involved in AR organogenesis, which suggests a separate set of regulators exists (Sorin et al., 2005; Gutierrez et al., 2009, 2012; Bellini et al., 2014). Further support for an independent regulation of AR and LR is the Arabidopsis monopteros mutant, which does not form a functional PR but does develop AR (Przemeck et al., 1996; Bellini et al., 2014). Hence, LR and AR share certain signaling elements but also depend on root-type specific signaling components. In addition to unique auxin-dependent regulators also cytokinin specifically controls either root-type. The WOODEN LEG wol3 mutants, defective for the cytokinin receptor ARABIDOPSIS HISTIDINE KINASE 4 (AHK4), shows defects of vascular development in the PR and LR but not in de novo initiated AR (Kuroha et al., 2006; Kuroha and Satoh, 2007). Also the A. thaliana pectin methylesterase 3 gene has a specific role during AR development. This gene is expressed in vascular tissues and mutants do not show defects in LR but develop more AR (Guénin et al., 2011). As vascular development is a common nominator between the 
latter genes, regulators of vascular development might differentiate between different root-types. Some of the temperature-sensitive Arabidopsis mutants identified by Konishi and Sugiyama (2003), are specifically affected in AR development. For example the root initiation defective1 (rid1) mutant fails to initiate ARP in the hypocotyl, but still initiates LR in PR segments (Konishi and Sugiyama, 2003). Specifc cell-wall-remodeling proteins are important for LR development, without having a role during AR initiation (Lewis et al., 2013). Auxin transport is important for both root-types, but whereas PIN proteins are important during LR development (Benková et al., 2003; Laskowski et al., 2008; Lewis etal., 2011; Marhavy etal., 2013), ABCB19 has a more pivotal role in hypocotyl-based AR formation (Sukumar etal., 2013).

\section{HORMONES WITH DIFFERENTIAL ROLE IN PR BRANCHING OR HYPOCOTYL AR}

Auxin can been seen as the main regulator of rooting competence, but other plant growth regulators might contribute to the finetuning of the rooting response or they act during the steps at which the root identity is obtained.

The volatile plant growth regulator, ethylene, is probably the hormone that differentiates most between root-types. In many species, ethylene is found to have a positive effect on AR development and emergence. For example in mung bean or sunflower hypocotyl cuttings, prolonged exposure to exogenous 1-aminocyclopropane-1-carboxylic acid (ACC), the precursor of ethylene, results in increased root numbers (Jusaitis, 1986; Liu et al., 1990; Pan et al., 2002). Also in other species, such as Rumex and the monocots maize and rice, exogenous ethylene has a positive effect on AR formation (Drew et al., 1979, 1989). In both Arabidopsis and tomato mutants that overproduce ethylene or have a constitutive response to ethylene (resp. eto1, ctr1, and epi), lower numbers of LR are recorded, while in the ethylene-insensitive mutants (ein2 and $\mathrm{Nr}$ ) more root branches are formed (Negi et al., $2008,2010)$. However, in tomato hypocotyls the function of ethylene is opposite and ethylene promotes the formation of AR (Clark et al., 1999; Negi et al., 2010). In A. thaliana however, this stimulatory role of ethylene on AR formation is not observed. In Petunia, reduced AR formation is observed in ethylene-insensitive plants (Clark et al., 1999). It often is suggested that ethylene is needed to elicit rhizogenesis in the presence of auxin and probably functions through interaction with auxin sensitivity and transport (Riov and Yang, 1989; Ro̊žička et al., 2007; Negi et al., 2010; Strader et al., 2010; Lewis et al., 2011). However, whereas ethylene and auxin interact to inhibit root growth, ethylene acts independent of auxin signaling in etiolated Arabidopsis hypocotyls (Stepanova et al., 2007). Consequently we conclude that different tissues have a different sensitivity to the same growth regulator and the tissue thus determines the organogenic responses.

The contrasting effects of ethylene in Arabidopsis and tomato may reflect a differential adaptation to flooding. Tomato is sensitive to water-logging and moisture, and the formation of $\mathrm{AR}$ is started shortly after submergence (McNamara and Mitchell, 1991). The submergence of the hypocotyl of tomato seedlings and the subsequent oxygen shortage, stimulates ethylene production and induces hypocotyl-based AR formation (Vidoz et al., 2010). Also in sunflower and Rumex, water-logging results in AR formation, stimulated by ethylene (Wample and Reid, 1979; Visser et al., $1996 a, b)$. In rice, ethylene is important for the induction of epidermal cell death to facilitate AR emergence, a process that is floodingand anoxia-dependent (Mergermann and Sauter, 2000; Steffens et al., 2006). In these cases, ethylene modulates auxin transport and the resulting auxin accumulation stimulates AR formation. Besides its role in flooding and anoxia, ethylene also functions in wounding responses, which may be linked with AR formation in cuttings (O'Donnell et al., 1996). Moreover, ethylene does not only interact with auxin, but the complex interactions between ethylene, GA and ABA in deepwater rice illustrates the importance of finely regulated hormone interactions during AR formation (Steffens et al., 2006).

Jasmonates are stress-related hormones that are rapidly synthesized upon wounding but also are involved in developmental processes (Creelman et al., 1992; Glauser et al., 2008; Koo et al., 2009). Methyl jasmonate (MeJA) is shown to inhibit PR growth, while it promotes LR formation in Arabidopsis and rice (Raya-Gonzalez et al., 2012; Hsu et al., 2013). In the JA receptor mutant coil, LR-positioning is disturbed and JA acts both through an auxin-dependent and an auxin-independent pathway (Raya-Gonzalez et al., 2012). MeJA stimulates AR initiation in tobacco thin cell layers (Fattorini et al., 2009). In stem cuttings of Petunia however, JA accumulating at the base and inhibits AR emergence (Ahkami et al., 2009). In the Arabidopsis hypocotyl, JA negatively regulates AR development (Gutierrez et al., 2012). JA therefore shows opposing effects on root formation depending on the plant organ: hypocotyl, stem, or root.

Both strigolactones and GA have an inhibitory role during AR and LR induction. In the presence of the synthetic strigolactone analogs, GR24 or CISA, AR formation is strongly reduced, whereas inhibition of LR development much less pronounced (Koltai et al., 2010; Kapulnik et al., 2011; Ruyter-Spira et al., 2011; Rasmussen et al., 2012, 2013; Brewer et al., 2013). GA treatment in Arabidopsis hypocotyls inhibits adventitious rooting (Mauriat et al., 2014). This is in line with earlier reports in which ectopic increase of GA production in the stem of tobacco and rice was shown to reduce AR induction (Lo et al., 2008; Niu et al., 2013). Similarly, GA-deficient and GA-insensitive transgenic Populus, show increased LR proliferation (Gou et al., 2010). GA primarily reduces polar auxin transport, thereby limiting the auxin availability for the induction of cell divisions (Gou et al., 2010; Niu et al., 2013; Mauriat et al., 2014). A more specialized regulation of root induction by GA is observed in deep water rice, where GA promotes AR initiation through interactions with ethylene (Steffens et al., 2006). The stress hormone ABA, negatively regulates LR initiation and development (Signora et al., 2001; De Smet et al., 2003). Despite the role of ABA in wound responses, the establishment of a sink and QC development, the role of ABA in AR development has not been investigated in detail yet. Moreover, contradicting findings about positive and negative effects are reported. This indicates that subtle differences in the plant state or in the interactions with other plant growth regulators affect the outcome of ABAsignaling. Cytokinins counteract the root-stimulating effect of auxin in both LR and AR organogenesis, are important for the establishment of a functional meristem in both root-types and 
therefore have no root-type differential role (Della Rovere et al., 2013).

In addition to hormonal factors, also signaling factors, such as nitric oxide (NO) determine the rooting responses. $\mathrm{NO}$ is related to stress responses and NO-production is enhanced under elevated $\mathrm{CO}_{2}$ conditions and after wounding (Wang et al., 2013). $\mathrm{NO}$ is an essential factor to determine the rooting potential of juvenile cuttings (Abu-Abied et al., 2012). In eucalypt, high NOconcentrations are correlated with a higher capacity to form AR, but in Arabidopsis constitutive expression of nitrate reductase does not affect the formation of either LR or AR (Abu-Abied et al., 2012). Moreover, NO and cyclic GMP function as messengers acting downstream of auxin during AR formation in cucumber hypocotyls (Pagnussat et al., 2003, 2004). NO regulates cell divisions and organogenic processes in a calcium-dependent way (Lanteri et al., 2006). NO is emerging as a player in LR development because local, peroxisomal IBA to IAA conversion is important for LR formation and $\mathrm{NO}$ acts as a signal during this process (Mendez-Bravo et al., 2010; De Rybel et al., 2012; Schlicht et al., 2013). Moreover, NO interacts with other hormone signaling pathways (Simontacchi et al., 2013). NO-homeostasis is regulated by the plant hormone cytokinin and direct interaction between NO and cytokinin suppresses the action of NO (Liu et al., 2013). This correlates with the negative action of NO during AR development and the inhibitory role of cytokinin on AR formation is at least partly mediated through NO. Polyamines and hydrogen peroxide are other important signaling molecules in AR development (Nag et al., 2001; Couee et al., 2004; Bai et al., 2007; Kevers et al., 2009; Liao et al., 2009; Ragonezi et al., 2010). Polyamines regulate cell divisions, the sensitivity to endogenous auxin, differentiation and regulate ethylene-biosynthesis to translate environmental changes into root development (Couee et al., 2004; Naija et al., 2008).

\section{ENVIRONMENTAL FACTORS WITH DIFFERENTIAL EFFECT ON AR AND LR FORMATION}

The different role of plant growth regulators and signaling factors, requires a tight control of initiation and emergence fine-tuning during the development of different root-types. As hormones are translators of environmental conditions, the above mentioned differences most likely represent environmental conditions that differentiate between AR and LR formation (Rubio et al., 2009). The plant root system is responsible for the acquisition of water and nutrients from soil and it is embedded in a complex environment with biotic and abiotic interactions. It is therefore not surprising that the root system architecture is highly influenced by environmental signals, such as water availability and nutrient concentration (Malamy, 2005; Monshausen and Gilroy, 2009). Different root-types flexibly respond to the environmental conditions and generate a root system that allows plants to perform well in their growth conditions (Hodge, 2004; Jones and Ljung, 2012).

Whereas in some species, AR initiate spontaneously, in other species AR are only formed upon stresses such as wounding or flooding or induced by nutrient shortage. Both in plant cuttings and in intact plants, wounding-associated dedifferentiation is often a requirement to form roots (da Costa et al., 2013). Upon PR damage or excision of cuttings, wound-induced AR assist the plant's survival. Upon wounding, auxin accumulates rapidly at the base of a segment and stimulates cell divisions in this region (De Klerk et al., 1999). Auxin accumulation also stimulates the creation of a carbohydrate sink, which is an additional stimulants for AR development (Agulló-Antón et al., 2011). In Arabidopsis, removal of the PR leads to rapid AR induction at the hypocotyl base (Sukumar et al., 2013), but AR formation also takes place without wounding in etiolated hypocotyls (Sorin et al., 2005).

A general tendency is that roots branch more in nutrientrich conditions (Robinson, 1994; López-Bucio et al., 2003; Hodge, 2004; Krouk et al., 2011). High nitrate inhibits LR development, while low nitrate has no effect on PR growth and promotes LR initiation (Robinson, 1994; Zhang et al., 1999; Signora et al., 2001). ABA mediates these nitrate effects (Signora et al., 2001; De Smet et al., 2003, 2006b). The direct relation between nitrogenavailability and AR development still needs to be evaluated, but in horticultural species, such as in rose, addition of nitrate or ammonia does not affect AR formation (Hyndman et al., 1981). Nitrogen also affects the formation of aerenchyma in AR and thereby improves the oxygen exchange (Drew et al., 1989; He et al., 1992). Phosphorous on the other hand has a different effect on different root-types. Due to the poor mobility in the soil, phosphorous often is a limiting growth factor (Abel, 2011). Plants optimize their development to maximize phosphate usage by branching and the formation of AR in the top soil stratum. Low phosphate does not affect basal PR growth or LR induction, but it preferentially stimulates newly initiated AR on the hypocotyl and lower stems (Lynch and Brown, 2001; Williamson et al., 2001; Walk et al., 2006). Possibly, the phosphate responses occur via interaction with auxin perception, signaling and redistribution (López-Bucio et al., 2002, 2005; Al-Ghazi et al., 2003; Nacry etal., 2005; Pérez-Torres et al., 2008; Jones and Ljung, 2012). During phosphate deficiency, strigolactones are important and their biosynthesis is directly regulated by the presence of phosphorous (López-Ráez et al., 2008; Yoneyama et al., 2012; Foo et al., 2013). Strigolactones have both a direct and an indirect effect on root responses, via the induction of the auxin receptor TIR1 (Kapulnik etal., 2011; Ruyter-Spira et al., 2011; Mayzlish-Gati et al., 2012). In general, AR are considered beneficial to sustain shoot growth and the formation of AR is more energy-efficient than other root-types depending on the nutrient-availability. Thanks to the presence of aerenchyma, which enhances gas exchange, AR formation has advantages for the plant (Miller et al., 2003; Ochoa et al., 2006). However, research describing AR development in nutrient-deprived conditions is limited.

Besides nutrients, also water is essential for plant growth. To increase water-use efficiency in water-limiting conditions, PR elongation is promoted to reach deeper water resources (GarayArroyo et al., 2012; Jones and Ljung, 2012; Xu et al., 2013). ABA translates the soil water status into root development. In addition to the effect on the PR elongation, LR initiation and development are inhibited by drought through interactions of $\mathrm{ABA}$, auxin and cytokinin (Signora et al., 2001; De Smet et al., 2003, 2006b; Malamy, 2005; Shkolnik-Inbar and Bar-Zvi, 2010; Xu et al., 2013). Prolonged drought stress results in the development of a short PR 


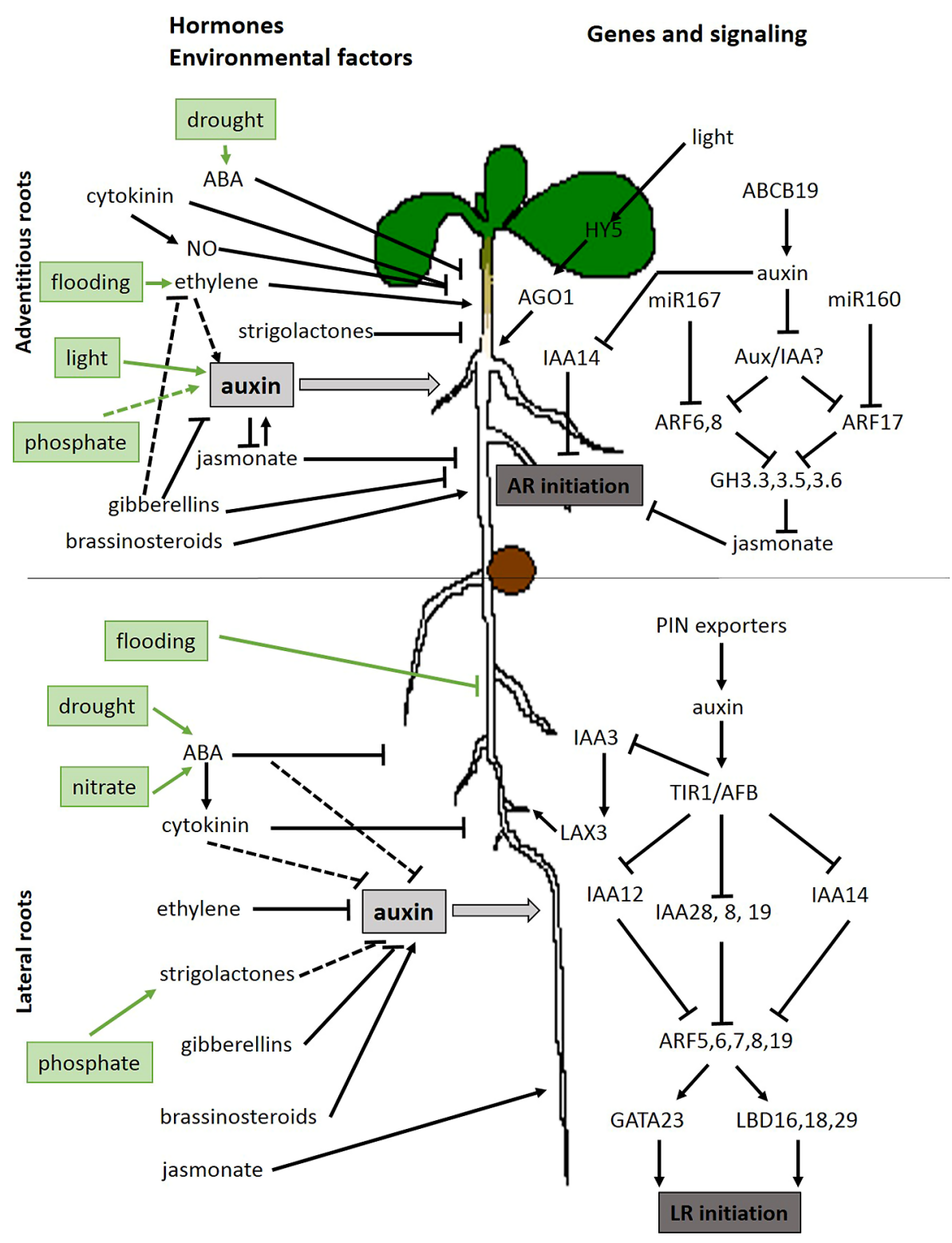

FIGURE 1 | Overview of hormonal, environmental, and genetic factors involved in adventitious roots developing from the hypocotyl and lateral root initiation on the primary root. Dashed lines represent possible interactions. Full lines represent published interactions (references throughout this article). Positive interactions are indicated with a sharp arrowhead and negative interactions with a blunt arrowhead.

and dormant LR, which rapidly resume growth upon rehydration (Vartanian et al., 1994; Zolla et al., 2010; Sreenivasulu et al., 2012). Similarly, AR development could be inhibited by drought, but research about the effect of drought on AR development or the involvement of ABA in the regulation of AR formation is limited. Submergence or flooding on the other hand, induce AR to replace the basal root system (Voesenek et al., 1996; Mergermann and Sauter, 2000; Ahmed etal., 2013; Sauter, 2013). The main reason for this response is the lack of oxygen, which hampers nutrient- and water-uptake in the PR (Bailey-Serres and Voesenek, 2008; Calvo-Polanco et al., 2012) and as an adaptation, stem- or node-borne AR are formed to replace soil-borne roots (Vidoz et al.,
2010). The metabolic costs to maintain the PR are higher than the costs to form AR, so the initiation of AR is a logical tradeoff for the root system (Miller et al., 2003; Walk et al., 2006). Upon submergence, plant species adopt two strategies: either de novo formation of ARP [e.g., in tomato and sunflower (Wample and Reid, 1976, 1979; Negi et al., 2010)] or emergence of dormant ARP, such as in Poaceae (Malamy, 2005; Steffens et al., 2006). Ethylene acts in both strategies and increase auxin transport and the sensitivity to auxin in the rooting zones, thereby promoting the formation of $\mathrm{AR}$ and the emergence of pre-formed root initials. AR grow horizontally with more access to oxygen and contain aerenchyma, in which gas exchange occurs efficiently (Gaxiola et al., 2010; Abiko 
etal., 2012; Ahmed etal., 2013). Besides the supply of oxygen, AR have higher hydraulic conductivity and thus supply the plants with sufficient water to sustain development (Calvo-Polanco et al., 2012).

\section{CONCLUSION}

In A. thaliana the PR, LR, and AR together form a flexible root system that is capable to adapt to changing environmental conditions. Despite the complex mix of different root-types, physiological and genetic studies have started to pinpoint specific factors to determine root identity and to control the development of one root-type over another. We believe that LR and AR share pathways, but that both root-types also have a specific set of signaling components. Because both root-types have functional similarities and differences, the different pathways intertwine at certain positions. Although some signaling factors are shared, additional research is required to draw the complex map of all interacting factors (da Costa et al., 2013). On the other hand, other factors uniquely regulate one specific root-type and help to control the investment of a plant in either the PR system or secondary AR. These factors are both genetic, hormonal and environmental, and also the plant's endogenous conditions affects the rooting capacity. An overview of the hormonal, environmental and genetic factors involved in the generation of lateral or (ARs) is given in Figure 1. A difference in tissue origin affects the regulation of the organogenic response and the conditions in the hypocotyl pericycle differ from those in a similar cell layer in the PR. Moreover, also the formation of stem-based AR is regulated by different factors than hypocotyl AR (Verstraeten et al., 2013; Welander et al., 2014). We only just started to decipher differences in PR, LR, and AR root development and more research will lead to a better understanding of the different root-types and treatments to optimize plant growth in all conditions.

\section{REFERENCES}

Abel, S. (2011). Phosphate sensing in root development. Curr. Opin. Plant Biol. 14, 303-309. doi: 10.1016/j.pbi.2011.04.007

Abiko, T., Kotula, L., Shiono, K., Malik, A. I., Colmer, T. D., and Nakazono, M. (2012). Enhanced formation of aerenchyma and induction of a barrier to radial oxygen loss in adventitious roots of Zea nicaraguensis contribute to its waterlogging tolerance as compared with maize (Zea mays ssp mays). Plant Cell Environ. 35, 1618-1630. doi: 10.1111/j.1365-3040.2012.02513.x

Abu-Abied, M., Szwerdszarf, D., Mordehaev, I., Levy, A., Stelmakh, O. R., Belausov, E., et al. (2012). Microarray analysis revealed upregulation of nitrate reductase in juvenile cuttings of Eucalyptus grandis, which correlated with increased nitric oxide production and adventitious root formation. Plant J. 71, 787-799. doi: 10.1111/j.1365-313X.2012.05032.x

Achard, P., Gusti, A., Cheminant, S., Alioua, M., Dhondt, S., Coppens, F., et al. (2009). Gibberellin signaling controls cell proliferation rate in Arabidopsis. Curr. Biol. 19, 1188-1193. doi: 10.1016/j.cub.2009.05.059

Agulló-Antón, M. A., Sánchez-Bravo, J., Acosta, M., and Druege, U. (2011). Auxins or sugars: What makes the difference in the adventitious rooting of stored carnation cuttings? J. Plant Growth Regul. 30, 100-113. doi: 10.1007/s00344-0109174-8

Ahkami, A. H., Lischewski, S., Haensch, K. T., Porfirova, S., Hofmann, J., Rolletschek, H., et al. (2009). Molecular physiology of adventitious root formation in Petunia hybrida cuttings: involvement of wound response and primary metabolism. New Phytol. 181, 613-625. doi: 10.1111/j.1469-8137.2008.02704.x

Ahmed, F., Rafii, M., Ismail, M. R., Juraimi, A. S., Rahim, H. A., Asfaliza, R., et al. (2013). Waterlogging tolerance of crops: breeding, mechanism of tolerance, molecular approaches, and future prospects. Biomed Res. Int. 2013:963525. doi: $10.1155 / 2013 / 963525$
Al-Ghazi, Y., Muller, B., Pinloche, S., Tranbarger, T. J., Nacry, P., Rossignol, M., et al. (2003). Temporal responses of Arabidospis root architecture to phosphate starvation: evidence for the involvement of auxin signaling. Plant Cell Environ. 26, 1053-1066. doi: 10.1046/j.1365-3040.2003.01030.x

Bai, L., Zhou, Y., Zhang, X. R., Song, C. P., and Cao, M. Q. (2007). Hydrogen peroxide modulates abscisic acid signaling in root growth and development in Arabidopsis. Chin. Sci. Bull. 52, 1142-1145. doi: 10.1007/s11434-007-0179-z

Bailey-Serres, J., and Voesenek, L. (2008). Flooding stress: acclimations and genetic diversity. Annu. Rev. Plant Biol. 59, 313-339. doi: 10.1146/annurev.arplant.59.032607.092752

Bao, F., Shen, J., Brady, S. R., Muday, G. K., Asami, T., and Yang, Z. (2004). Brassinosteroids interact with auxin to promote lateral root development in Arabidopsis. Plant Physiol. 134, 1624-1631. doi: 10.1104/pp.103.036897

Beeckman, T., Burssens, S., and Inze, D. (2001). The peri-cell-cycle in Arabidopsis. J. Exp. Bot. 52, 403-411. doi: 10.1093/jexbot/52.suppl_1.403

Beemster, G. T. S., and Baskin, T. I. (1998). Analysis of cell division and elongation underlying the developmental acceleration of root growth in Arabidopsis thaliana. Plant Physiol. 116, 1515-1526. doi: 10.1104/pp.116.4.1515

Bellamine, J., Penel, C., Greppin, H., and Gaspar, T. (1998). Confirmation of the role of auxin and calcium in the late phases of adventitious root formation. Plant Growth Regul. 26, 191-194. doi: 10.1023/A:1006182801823

Bellini, C., Pacurar, D. I., and Perrone, I. (2014). Adventitious roots and lateral roots: similarities and differences. Annu. Rev. Plant Biol. 65, 639-666. doi: 10.1146/annurev-arplant-050213-035645

Benková, E., and Bielach, A. (2010). Lateral root organogenesis - from cell to organ. Curr. Opin. Plant Biol. 13, 677-683. doi: 10.1016/j.pbi.2010.09.006

Benková, E., Michniewicz, M., Sauer, M., Teichmann, T., Seifertová, D., Jürgens, G., et al. (2003). Local, efflux-dependent auxin gradients as a common module for plant organ formation. Cell 115, 591-602. doi: 10.1016/S0092-8674(03)00924-3

Bhalerao, R. P., Eklof, J., Ljung, K., Marchant, A., Bennett, M., and Sandberg, G. (2002). Shoot-derived auxin is essential for early lateral root emergence in Arabidopsis seedlings. Plant J. 29, 325-332. doi: 10.1046/j.0960-7412.2001.01217.x

Bielach, A., Podlesakova, K., Marhavy, P., Duclercq, J., Cuesta, C., Muller, B., et al. (2012). Spatiotemporal regulation of lateral root organogenesis in Arabidopsis by cytokinin. Plant Cell 24, 3967-3981. doi: 10.1105/tpc.112.103044

Birnbaum, K., Shasha, D. E., Wang, J. Y., Jung, J. W., Lambert, G. M., Galbraith, D. W., et al. (2003). A gene expression map of the Arabidopsis root. Science 302, 1956-1960. doi: 10.1126/science.1090022

Bishopp, A., Help, H., El-Showk, S., Weijers, D., Scheres, B., Friml, J., et al. (2011a). A mutually inhibitory interaction between auxin and cytokinin specifies vascular pattern in roots. Curr. Biol. 21, 917-926. doi: 10.1016/j.cub.2011.04.017

Bishopp, A., Lehesranta, S., Váten, A., Help, H., El-Showk, S., Scheres, B., et al. (2011b). Phloem-transported cytokinin regulates polar auxin transport and maintains vascular pattern in the root meristem. Curr. Biol. 21, 927-932. doi: 10.1016/j.cub.2011.04.049

Boerjan, W., Cervera, M. T., Delarue, M., Beeckman, T., Dewitte, W., Bellini, C., et al. (1995). Superroot, a recessive mutation in Arabidopsis, confers auxin overproduction. Plant Cell 7, 1405-1419. doi: 10.1105/tpc.7.9.1405

Brewer, P. B., Koltai, H., and Beveridge, C. A. (2013). Diverse roles of strigolactones in plant development. Mol. Plant 6, 18-28. doi: 10.1093/mp/sss130

Calvo-Polanco, M., Senorans, J., and Zwiazek, J. J. (2012). Role of adventitious roots in water relations of tamarack (Larix laricina) seedlings exposed to flooding. BMC Plant Biol. 12:99. doi: 10.1186/1471-2229-12-99

Campanoni, P., and Nick, P. (2005). Auxin-dependent cell division and cell elongation. 1-Naphthaleneacetic acid and 2,4-Dichlorophenoxyacetic acid activate different pathways. Plant Physiol. 137, 939-948. doi: 10.1104/pp.104.053843

Casimiro, I., Beeckman, T., Graham, N., Bhalerao, R., Zhang, H. M., Casero, P., et al. (2003). Dissecting Arabidopsis lateral root development. Trends Plant Sci. 8, 165-171. doi: 10.1016/S1360-1385(03)00051-7

Casimiro, I., Marchant, A., Bhalerao, R. P., Beeckman, T., Dhooge, S., Swarup, R., et al. (2001). Auxin transport promotes Arabidopsis lateral root initiation. Plant Cell 13, 843-852. doi: 10.1105/tpc.13.4.843

Casson, S. A., and Lindsey, K. (2003). Genes and signalling in root development. New Phytol. 158, 11-38. doi: 10.1046/j.1469-8137.2003.00705.x

Celenza, J. L., Grisafi, P. L., and Fink, G. R. (1995). A pathway forl lateral root formation in Arabidopsis thaliana. Genes Dev. 9, 2131-2142. doi: 10.1101/gad.9.17.2131

Chapman, E. J., and Estelle, M. (2009). Cytokinin and auxin intersection in root meristems. Genome Biol. 10, 210. doi: 10.1186/gb-2009-10-2-210 
Chapman, E. J., Greenham, K., Castillejo, C., Sartor, R., Bialy, A., Sun, T. P., et al. (2012). Hypocotyl transcriptome reveals auxin regulation of growth-promoting genes through GA-dependent and -independent pathways. PLoS ONE 7:e36210. doi: 10.1371/journal.pone.0036210

Clark, D. G., Gubrium, E. K., Barrett, J. E., Nell, T. A., and Klee, H. J. (1999). Root formation in ethylene-insensitive plants. Plant Physiol. 121, 53-59. doi: 10.1104/pp.121.1.53

Couee, I., Hummel, I., Sulmon, C., Gouesbet, G., and El Amrani, A. (2004). Involvement of polyamines in root development. Plant Cell Tissue Organ Cult. 76, 1-10. doi: 10.1023/A:1025895731017

Cowling, R. J., and Harberd, N. P. (1999). Gibberellins control Arabidopsis hypocotyl growth via regulation of cellular elongation. J. Exp. Bot. 50, 1351-1357. doi: 10.1093/jxb/50.337.1351

Creelman, R. A., Tierney, M. L., and Mullet, J. E. (1992). Jasmonic acid/methyl jasmonate accumulate in wounded soybean hypocotyls and modulate wound gene expression. Proc. Natl. Acad. Sci. U.S.A. 89, 4938-4941. doi: 10.1073/pnas.89.11.4938

da Costa, C. T., De Almeida, M. R., Ruedell, C. M., Schwambach, J., Maraschin, F. S., and Fett-Neto, A. G. (2013). When stress and development go hand in hand: main hormonal controls of adventitious rooting in cuttings. Front. Plant Sci. 4:133. doi: 10.3389/fpls.2013.00133

da Rocha Corrêa, L., Stein, R. J., and Fett-Neto, A. G. (2012a). Adventitious rooting of detached Arabidopsis thaliana leaves. Biol. Plant. 56, 25-30. doi: 10.1007/s10535012-0011-8

da Rocha Corrêa, L., Troleis, J., Mastroberti, A. A., Mariath, J. E. A., and Fett-Netto, A. G. (2012b). Distinct modes of adventitious rooting in Arabidopsis thaliana Plant Biol. 14, 100-109. doi: 10.1111/j.1438-8677.2011.00468.x

Dastidar, M. G., Jouannet, V., and Maizel, A. (2012). Root branching: mechanisms, robustness and plasticity. WIREs Dev. Biol. 1, 329-343. doi: 10.1002/wdev.17

Davis, T. D., and Haissig, B. E. (1994). Biology of Adventitious Root Formation. New York: Plenum Press.

De Grauwe, L., Vandenbussche, F., Tietz, O., Palme, K., and Van Der Straeten, D. (2005). Auxin, ethylene and brassinosteroids: tripartite control of growth in the Arabidopsis hypocotyl. Plant Cell Physiol. 46, 827-836. doi: 10.1093/pcp/pcil11

De Klerk, G. J., Keppel, M., Terbrugge, J., and Meekes, H. (1995). Timing of the phases in adventitious root formation in apple microcuttings. J. Exp. Bot. 46, 965-972. doi: 10.1093/jxb/46.8.965

De Klerk, G. J., Van Der Krieken, W., and De Jong, J. C. (1999). Review - The formation of adventitious roots: new concepts, new possibilities. In Vitro Cell. Dev. Biol. Plant 35, 189-199. doi: 10.1007/s11627-999-0076-Z

Delay, C., Imin, N., and Djordjevic, M. A. (2013). Regulation of Arabidopsis root development by small signaling peptides. Front. Plant Sci. 4:352. doi: 10.3389/fpls.2013.00352

Della Rovere, F., Fattorini, L., D’Angeli, D., Veloccia, A., Falasca, G., and Altamura, M. M. (2013). Auxin and cytokinin control formation of the quiescent centre in the adventitious root apex of Arabidopsis. Ann. Bot. 112, 1395-1407. doi $10.1093 / \mathrm{aob} / \mathrm{mct} 215$

Dello Ioio, R., Linhares, F. S., Scacchi, E., Casamitjana-Martinez, E., Heidstra, R., Costantino, P., etal. (2007). Cytokinins determine Arabidopsis root-meristem size by controlling cell differentiation. Curr. Biol. 17, 678-682. doi: 10.1016/j.cub.2007.02.047

Den Herder, G., Van Isterdael, G., Beeckman, T., and De Smet, I. (2010). The roots of a new green revolution. Trends Plant Sci. 15, 600-607. doi: 10.1016/j.tplants.2010.08.009

De Rybel, B., Audenaert, D., Xuan, W., Overvoorde, P., Strader, L. C., Kepinski, S., et al. (2012). A role for the root cap in root branching revealed by the non-auxin probe naxillin. Nat. Chem. Biol. 8, 798-805. doi: 10.1038/nchembio.1044

De Rybel, B., Vassileva, V., Parizot, B., Demeulenaere, M., Grunewald, W. Audenaert, D., etal. (2010). A novel aux/IAA28 signaling cascade activates GATA23-dependent specification of lateral root founder cell identity. Curr. Biol. 20, 1697-1706. doi: 10.1016/j.cub.2010.09.007

De Smet, I. (2012). Lateral root initiation: one step at a time. New Phytol. 193, 867-873. doi: 10.1111/j.1469-8137.2011.03996.x

De Smet, I., Signora, L., Beeckman, T., Inze, D., Foyer, C. H., and Zhang, H. M. (2003). An abscisic acid-sensitive checkpoint in lateral root development of Arabidopsis. Plant J. 33, 543-555. doi: 10.1046/j.1365-313X.2003.01652.x

De Smet, I., Tetsumura, T., De Rybel, B., Frei Dit Frey, N., Laplaze, L., Casimiro, I., et al. (2007). Auxin-dependent regulation of lateral root positioning in the basal meristem of Arabidopsis. Development 134, 681-690. doi: 10.1242/dev. 02753

De Smet, I., Vanneste, S., Inze, D., and Beeckman, T. (2006a). Lateral root initiation or the birth of a new meristem. Plant Mol. Biol. 60, 871-887. doi: 10.1007/s11103005-4547-2

De Smet, I., Zhang, H. M., Inze, D., and Beeckman, T. (2006b). A novel role for abscisic acid emerges from underground. Trends Plant Sci. 11, 434-439. doi: 10.1016/j.tplants.2006.07.003

De Smet, I., Vassileva, V., De Rybel, B., Levesque, M. P., Grunewald, W., Van Damme, D., et al. (2008). Receptor-like kinase ACR4 restricts formative cell divisions in the Arabidopsis root. Science 332, 594-597. doi: 10.1126/science.1160158

Dolan, L., Janmaat, K., Willemsen, V., Linstead, P., Poethig, S., Roberts, K., et al. (1993). Cellular organisation of the Arabidopsis thaliana root. Development 119, 71-84.

Drew, M. C., He, C. J., and Morgan, P. W. (1989). Decreased ethylene biosynthesis, and induction of aerenchyma, by nitrogen- or phosphate-starvation in adventitious roots of Zea mays L. Plant Physiol. 1, 266-271. doi: 10.1104/pp.91.1.266

Drew, M. C., Jackson, A. C., and Giffard, S. (1979). Ethylene-promoted adventitious rooting and development of cortical air spaces (aerenchyma) in roots may be adaptive responses to flooding in Zea mays L. Planta 147, 83-88. doi: 10.1007/BF00384595

Falasca, G., and Altamura, M. M. (2003). Histological analysis of adventitious rooting in Arabidopsis thaliana (L.) Heynh seedlings. Plant Biosyst. 137, 265-273. doi: 10.1080/11263500312331351511

Falasca, G., Zaghi, D., Possenti, M., and Altamura, M. M. (2004). Adventitious root formation in Arabidopsis thaliana thin cell layers. Plant Cell Rep. 23, 17-25. doi: 10.1007/s00299-004-0801-3

Fattorini, L., Falasca, G., Kevers, C., Rocca, L. M., Zadra, C., and Altamura, M. M. (2009). Adventitious rooting is enhanced by methyl jasmonate in tobacco thin cell layers. Planta 231, 155-168. doi: 10.1007/s00425-009-1035-y

Fernandez, A., Drozdzecki, A., Hoogewijs, K., Nguyen, A., Beeckman, T., Madder, A., et al. (2013). Transcriptional and functional classification of the GOLVEN/ROOT GROWTH FACTOR/CLE-like signaling peptides reveals their role in lateral root and hair rormation. Plant Physiol. 161, 954-970. doi: 10.1104/pp.112. 206029

Foo, E., Yoneyama, K., Hugill, C., Quittenden, L. J., and Reid, J. B. (2013). Strigolactones: internal and external signals in plant symbioses? Plant Signal. Behav. 8:e23168. doi: 10.4161/psb.23168

Fukaki, H., and Tasaka, M. (2009). Hormone interactions during lateral root formation. Plant Mol. Biol. 69, 437-449. doi: 10.1007/s11103-008-9417-2

Fukaki, H., Tameda, S., Masuda, H., and Tasaka, M. (2002). Lateral root formation is blocked by a gain-of-function mutation in the SOLITARY-ROOT/IAA14 gene of Arabidopsis. Plant J. 92, 153-168. doi: 10.1046/j.0960-7412.2001.01201.x

Garay-Arroyo, A., Sanchez, M. D., Garcia-Ponce, B., Azpeitia, E., and AlvarezBuylla, E. R. (2012). Hormone symphony during root growth and development. Dev. Dyn. 241, 1867-1885. doi: 10.1002/dvdy.23878

Gaxiola, A., Mcneill, S. M., and Coomes, D. A. (2010). What drives retrogressive succession? Plant strategies to tolerate infertile and poorly drained soils. Funct. Ecol. 24, 714-722. doi: 10.1111/j.1365-2435.2010.01688.x

Geiss, G., Gutierrez, L., and Bellini, C. (2009). "Adventitious root formation: new insights and perspectives," in Annual Plant Reviews: Root Development, Vol. 37, ed. T. Beeckman (Oxford: Wiley-Blackwell), 127-156.

Gendreau, E., Traas, J., Desnos, T., Grandjean, O., Caboche, M., and Höfte, H. (1997). Cellular basis of hypocotyl growth in Arabidopsis thaliana. Plant Physiol. 114, 295-305. doi: 10.1104/pp.114.1.295

Glauser, G., Grata, E., Dubugnon, L., Rudaz, S., Farmer, E. E., and Wolfender, J. L. (2008). Spatial and temporal dynamics of jasmonate synthesis and accumulation in Arabidopsis in response to wounding. J. Biol. Chem. 283, 16400-16407. doi: 10.1074/jbc.M801760200

Goh, T., Joi, S., Mimura, T., and Fukaki, H. (2012a). The establishment of asymmetry in Arabidopsis lateral root founder cells is regulated by LBD16/ASL18 and related LBD/ASL proteins. Development 139, 883-893. doi: 10.1242/dev.071928

Goh, T., Kasahara, H., Mimura, T., Kamiya, Y., and Fukaki, H. (2012b). Multiple AUX/IAA-ARF modules regulate lateral root formation: the role of Arabidopsis SHY2/IAA3-mediated auxin signalling. Philos. Trans. R. Soc. Lond. B Biol. Sci. 367, 1461-1468. doi: 10.1098/rstb.2011.0232

Gou, J., Strauss, S. H., Tsai, C. J., Fang, K., Chen, Y., Jiang, X., et al. (2010). Gibberellins regulate lateral root formation in Populus through interactions with 
auxin and other hormones. Plant Cell 22, 623-639. doi: 10.1105/tpc.109.0 73239

Guénin, S., Mareck, A., Rayon, C., Lamour, R., Assoumou, N. Y., Domon, J. M., et al. (2011). Identification of pectin methylesterase 3 as a basic pectin methylesterase isoform involved in adventitious rooting in Arabidopsis thaliana. New Phytol. 192 , 114-126. doi: 10.1111/j.1469-8137.2011.03797.x

Guo, D. L., Liang, J. H., and Li, L. (2009). Abscisic acid (ABA) inhibition of lateral root formation involves endogenous ABA biosynthesis in Arachis hypogaea L. Plant Growth Regul. 58, 173-179. doi: 10.1007/s10725-009-9365-0

Guo, D. L., Liang, J. H., Qiao, Y. C., Yan, Y. C., Li, L., and Dai, Y. H. (2012). Involvement of G1-to-S transition and AhAUX-dependent auxin transport in abscisic acid-induced inhibition of lateral root primodia initiation in Arachis hypogaea L. J. Plant Physiol. 169, 1102-1111. doi: 10.1016/j.jplph.2012. 03.014

Gutierrez, L., Bussell, J. D., Pacurar, D. I., Schwambach, J., Pacurar, M., and Bellini, C. (2009). Phenotypic plasticity of adventitious rooting in Arabidopsis is controlled by complex regulation of AUXIN RESPONSE FACTOR transcripts and microRNA abundance. Plant Cell 21, 3119-3132. doi: 10.1105/tpc.108.0 64758

Gutierrez, L., Mongelard, G., Flokova, K., Pacurar, D. I., Novak, O., Staswick, P., et al. (2012). Auxin controls Arabidopsis adventitious root initiation by regulating jasmonic acid homeostasis. Plant Cell 24, 2515-2527. doi: 10.1105/tpc.112. 099119

Haissig, B. E. (1974). Origins of adventitious roots. N. Z. J. For. Sci. 4, 299-310.

He, C. J., Morgan, P. W., and Drew, M. C. (1992). Enhanced sensitivity to ethylene in nitrogen-starved or phosphate-starved roots of Zea mays L. during aerenchyma formation. Plant Physiol. 98, 137-142. doi: 10.1104/pp.98.1.137

Himanen, K., Boucheron, E., Vanneste, S., Engler, J. D., Inze, D., and Beeckman, T. (2002). Auxin-mediated cell cycle activation during early lateral root initiation. Plant Cell 14, 2339-2351. doi: 10.1105/tpc.004960

Himanen, K., Vuylsteke, M., Vanneste, S., Vercruysse, S., Boucheron, E., Alard, P., et al. (2004). Transcript profiling of early lateral root initiation. Proc. Natl. Acad. Sci. U.S.A. 101, 5146-5151. doi: 10.1073/pnas.0308702101

Hochholdinger, F., Park, W. J., Sauer, M., and Woll, K. (2004). From weeds to crops: genetic analysis of root development in cereals. Trends Plant Sci. 9, 42-48. doi: 10.1016/j.tplants.2003.11.003

Hodge, A. (2004). The plastic plant: root responses to heterogeneous supplies of nutrients. New Phytol. 164, 9-24. doi: 10.1111/j.1469-8137.2004.01015.x

Hodge, A., Berta, G., Doussan, C., Merchan, F., and Crespi, M. (2009). Plant root growth, architecture and function. Plant Soil 321, 153-187. doi: 10.1007/s11104009-9929-9

Hsu, Y. Y., Chao, Y. Y., and Kao, C. H. (2013). Methyl jasmonate-induced lateral root formation in rice: the role of heme oxygenase and calcium. J. Plant Physiol. 170, 63-69. doi: 10.1016/j.jplph.2012.08.015

Hyndman, S. E., Hasegawa, P. M., and Bressan, R. A. (1981). The role of sucrose and nitrogen in adventitious root formation on cultured rose shoots. Plant Cell Tissue Organ Cult. 1, 229-238. doi: 10.1007/BF02318919

Jensen, P. J., Hamgarter, R. P., and Estelle, M. (1998). Auxin transport is required for hypocotyl elongation in light-grown but not dark-grown Arabidopsis. Plant Physiol. 116, 455-462. doi: 10.1104/pp.116.2.455

Jones, B., and Ljung, K. (2012). Subterranean space exploration: the development of root system architecture. Curr. Opin. Plant Biol. 15, 97-102. doi: 10.1016/j.pbi.2011.10.003

Jung, J. K. H., and McCouch, S. (2013). Getting to the roots of it: genetic and hormonal control of root architecture. Front. Plant Sci. 4:186. doi: 10.3389/fpls.2013.00186

Jusaitis, M. (1986). Rooting response of mung bean cuttings to 1 aminocyclopropane-1-carboxylic acid and inhibitors of ethylene biosynthesis. Sci. Hortic. 29, 77-85. doi: 10.1016/0304-4238(86)90033-6

Kapulnik, Y., Delaux, P. M., Resnick, N., Maylish-Gati, E., Wininger, S., Bhattacharya, C., et al. (2011). Strigolactones affect lateral root formation and root-hair elongation in Arabidopsis. Planta 233, 209-216. doi: 10.1007/s00425-0101310-y

Kell, D. B. (2011). Breeding crop plants with deep roots: their role in sustainable carbon, nutrient and water sequestration. Ann. Bot. 108, 407-418. doi: $10.1093 / \mathrm{aob} / \mathrm{mcr} 175$

Kevers, C., Hausman, J. F., Faivre-Rampant, O., Dommes, J., and Gaspar, T. (2009). "What we have learned about the physiology of in vitro adventitious rooting of woody plants and how it is relates to improvements in the practice," in Adventitious Root Formation of Forest Trees and Horticultural Plants-From Genes to Applications, ed. K. Niemi (Trivandrum: Research Signpost), 400-417.

Koltai, H., Dor, E., Hershenhorn, J., Joel, D. M., Weininger, S., Lekalla, S., et al. (2010). Strigolactones' effect on root growth and root hair elongation may be mediated by auxin efflux carriers. J. Plant Growth Regul. 29, 129-136. doi: 10.1007/s00344-009-9122-7

Konishi, M., and Sugiyama, M. (2003). Genetic analysis of adventitious root formation with a novel series of temperature-sensitive mutants of Arabidopsis thaliana. Development 130, 5637-5647. doi: 10.1242/dev.00794

Koo, A. J. K., Gao, X., Jones, D. A., and Howe, G. A. (2009). A rapid wound signal activates the systemic synthesis of bioactive jasmonates in Arabidopsis. Plant J. 59, 974-986. doi: 10.1111/j.1365-313X.2009.03924.x

Krouk, G., Ruffel, S., Gutiérrez, R. A., Gojon, A., Crawford, N. M., Coruzzi, G. M., et al. (2011). A framework integrating plant growth with hormones and nutrients. Trends Plant Sci. 16, 178-182. doi: 10.1016/j.tplants.2011.02.004

Kuroha, T., and Satoh, S. (2007). Involvement of cytokinins in adventitious and lateral root formation. Plant Root 1,27-33. doi: 10.3117/plantroot.1.27

Kuroha, T., Ueguchi, C., Sakakibara, H., and Satoh, S. (2006). Cytokinin receptors are required for normal development of auxin-transporting vascular tissues in the hypocotyl but not in adventitious roots. Plant Cell Physiol. 47, 234-243. doi: $10.1093 / \mathrm{pcp} / \mathrm{pci} 240$

Lanteri, M. L., Pagnussat, G. C., and Lamattina, L. (2006). Calcium and calciumdependent protein kinases are involved in nitric oxide- and auxin-induced adventitious root formation in cucumber. J. Exp. Bot. 57, 1341-1351. doi: 10.1093/jxb/erj109

Laplaze, L., Benkova, E., Casimiro, I., Maes, L., Vanneste, S., Swarup, R., et al. (2007). Cytokinins act directly on lateral root founder cells to inhibit root initiation. Plant Cell 19, 3889-3900. doi: 10.1105/tpc.107.055863

Laskowski, M. (2013). Lateral root initiation is a probabilistic event whose frequency is set by fluctuating levels of auxin response. J. Exp. Bot. 64, 2609-2617. doi: 10.1093/jxb/ert155

Laskowski, M., Grieneisen, V. A., Hofhuis, H., Hove, C. A., Hogeweg, P., Marée, A. F., et al. (2008). Root system architecture from coupling cell shape to auxin transport. PLoS Biol. 6:e307. doi: 10.1371/journal.pbio.0060307

Lavenus, J., Goh, T., Roberts, I., Guyomarc'h, S., Lucas, M., De Smet, I., et al. (2013). Lateral root development in Arabidopsis: fifty shades of auxin. Trends Plant Sci. 18, 450-458. doi: 10.1016/j.tplants.2013.04.006

Lewis, D. R., Negi, S., Sukumar, P., and Muday, G. K. (2011). Ethylene inhibits lateral root development, increases IAA transport and expression of PIN3 and PIN7 auxin efflux carriers. Development 138, 3485-3495. doi: 10.1242/dev. 065102

Lewis, D. R., Olex, A. L., Lundy, S. R., Turkett, W. H., Fetrow, J. S., and Muday, G. K. (2013). A kinetic analysis of the auxin transcriptome reveals cell wall remodeling proteins that modulate lateral root development in Arabidopsis. Plant Cell 25, 3329-3346. doi: 10.1105/tpc.113.114868

Liao, W. B., Xiao, H. L., and Zhang, M. L. (2009). Role and relationship of nitric oxide and hydrogen peroxide in adventitious root development of marigold. Acta Physiol. Plant. 31, 1279-1289. doi: 10.1007/s11738-009-0367-3

Li, S. W., Xue, L. G., Xu, S. J., Feng, H. Y., and An, L. Z. (2009). Mediators, genes and signaling in adventitious rooting. Bot. Rev. 75, 230-247. doi: 10.1007/s12229009-9029-9

Liu, J., Mukherjee, I., and Reid, D. M. (1990). Adventitious rooting in hypocotyls of sunflower (Helianthus annuus) seedlings. III. The role of ethylene. Physiol. Plant. 78, 268-276. doi: 10.1111/j.1399-3054.1990.tb02091.x

Liu, J., Rowe, J., and Lindsey, K. (2014). Hormonal crosstalk for root development: a combined experimental and modeling perspective. Front. Plant Sci. 5:116. doi: 10.3389/fpls.2014.00116

Liu, W. Z., Kong, D. D., Gu, X. X., Gao, H. B., Wang, J. Z., Xia, M., et al. (2013). Cytokinins act as suppressors of nitric oxide in Arabidopsis. Proc. Natl. Acad. Sci. U.S.A. 110, 1548-1553. doi: 10.1073/pnas.1213235110

Li, Y. H., Zou, M. H., Feng, B. H., Huang, X., Zhang, Z., and Sun, G. M. (2012). Molecular cloning and characterization of the genes encoding an auxin efflux carrier and the auxin influx carriers associated with the adventitious root formation in mango (Mangifera indica L.) cotyledon segments. Plant Physiol. Biochem. 55, 33-42. doi: 10.1016/j.plaphy.2012.03.012

Lo, S. F., Yang, S. Y., Chen, K. T., Hsing, Y. L., Zeevaart, J. A., Chen, L. J., et al. (2008). A novel class of gibberellin 2-oxidases control semidwarfism, tillering, 
and root development in Rice. Plant Cell 20, 2603-2618. doi: 10.1105/tpc.108.0 60913

López-Bucio, J., Cruz-RamíRez, A., and Herrera-Estrella, L. (2003). The role of nutrient availability in regulating root architecture. Curr. Opin. Plant Biol. 6, 280-287. doi: 10.1016/S1369-5266(03)00035-9

López-Bucio, J., Hernández-Abreu, E., Sánchez-Calderón, L., Nieto-Jacobo, M. F., Simpson, J., and Herrera-Estrella, L. (2002). Phosphate availability alters architecture an causes changes in hormone sensitivity in the Arabidopsis root system. Plant Physiol. 129, 244-256. doi: 10.1104/pp.010934

López-Bucio, J., Hernández-Abreu, E., Sánchez-Calderón, L., Pérez-Torres, C. A. Rampey, R. A., Bartel, B., et al. (2005). An auxin transport independent pathway is involved in phosphate stress-induced root architectural alterations in Arabidopsis. Identification of BIG as a mediator of auxin in pericycle cell activation. Plant Physiol. 137, 681-691. doi: 10.1104/pp.104.049577

López-Ráez, J. A., Charnikhova, T., Gómez-Roldán, V., Matusova, R., Kohlen, W., De Vos, R., et al. (2008). Tomato strigolactones are derived from carotenoids and their biosynthesis is promoted by phosphate starvation. New Phytol. 178, 863-874. doi: 10.1111/j.1469-8137.2008.02406.x

Lucas, M., Kenobi, K., Von Wangenheim, D., Vo $\beta$, U., Swarup, K., De Smet, I., et al. (2013). Lateral root morphogenesis is dependent on the mechanical properties of the overlaying tissue. Proc. Natl. Acad. Sci. U.S.A. 26, 5229-5234. doi: 10.1073/pnas.1210807110

Lucas, M., Swarup, R., Paponov, I. A., Swarup, K., Casimiro, I., Lake, D., et al. (2010). Short-root regulates primary, lateral and adventitious root development in Arabidopsis. Plant Physiol. 155, 384-398. doi: 10.1104/pp.110.165126

Ludwig-Müller, J., Vertocnik, A., and Town, C. D. (2005). Analysis of indole-3butyric acid-induced adventitious root formation on Arabidopsis stem segments. J. Exp. Bot. 56, 2095-2105. doi: 10.1093/jxb/eri208

Lynch, J. P. (2007). Roots of the second green revolution. Aust. J. Bot. 55, 493-512. doi: 10.1071/BT06118

Lynch, J. P., and Brown, K. M. (2001). Topsoil foraging - an architectural adaptation of plants to low phosphorus availability. Plant Soil 237, 225-237. doi: 10.1023/A:1013324727040

Lynch, J. P., and Brown, K. M. (2012). New roots for agriculture: exploiting the root phenome. Philos. Trans. R. Soc. Lond. B Biol. Sci. 367, 1598-1604. doi 10.1098/rstb.2011.0243

Mähönen, A. P., Bishopp, A., Higuchi, M., Nieminen, K. M., Kinoshita, K., Törmäkangas, K., etal. (2006). Cytokinin signaling and its inhibitor AHP6 regulate cell fate during vascular development. Science 311, 94-98. doi: $10.1126 /$ science. 1118875

Malamy, J. E. (2005). Intrinsic and environmental response pathways that regulate root system architecture. Plant Cell Environ. 28, 67-77. doi: 10.1111/j.13653040.2005.01306.x

Malamy, J. E., and Ryan, K. S. (2001). Environmental regulation of lateral root initiation in Arabidopsis. Plant Physiol. 127, 899-909. doi: 10.1104/pp.0 10406

Marhavy, P., Vanstraelen, M., De Rybel, B., Ding, Z. J., Bennett, M. J., Beeckman, T. et al. (2013). Auxin reflux between the endodermis and pericycle promotes lateral root initiation. EMBO J. 32, 149-158. doi: 10.1038/emboj.2012.303

Mauriat, M., Petterle, A., Bellini, C., and Moritz, T. (2014). Gibberellins inhibit adventitious rooting in hybrid aspen and Arabidopsis by affecting auxin transport. Plant J. 78, 372-384. doi: 10.1111/tpj.12478

Mayzlish-Gati, E., De-Cuyper, C., Goormachtig, S., Beeckman, T., Vuylsteke, M., Brewer, P. B., etal. (2012). Strigolactones are involved in root response to low phosphate conditions in Arabidopsis. Plant Physiol. 160, 1329-1341. doi: 10.1104/pp.112.202358

McNamara, S. T., and Mitchell, C. A. (1991). Roles of auxin and ethylene in adventitious root formation by a flood resistant tomato genotype. HortScience 26, $57-58$.

Mendez-Bravo, A., Raya-Gonzalez, J., Herrera-Estrella, L., and Lopez-Bucio, J. (2010). Nitric oxide is involved in alkamide-induced lateral root development in Arabidopsis. Plant Cell Physiol. 51, 1612-1626. doi: 10.1093/pcp/ pcq117

Mergermann, H., and Sauter, M. (2000). Ethylene induces epidermal cell death at the site of adventitious root emergence in rice. Plant Physiol. 124, 609-614. doi: 10.1104/pp.124.2.609

Miller, C. R., Ochoa, I., Nielsen, K. L., Beck, D., and Lynch, J. P. (2003). Genetic variation for adventitious rooting in response to low phosphorus availability: potential utility for phosphorus acquisition from stratified soils. Funct. Plant Biol. 30, 973-985. doi: 10.1071/FP03078

Monshausen, G. B., and Gilroy, S. (2009). The exploring root growth responses to local environmental conditions. Curr. Opin. Plant Biol. 12, 766-772. doi: 10.1016/j.pbi.2009.08.002

Moreno-Risueno, M. A., Van Norman, J. M., Moreno, A., Zhang, J. Y., Ahnert, S. E., and Benfey, P. N. (2010). Oscillating gene expression determines competence for periodic Arabidopsis root branching. Science 329, 1306-1311. doi: $10.1126 /$ science.1191937

Muday, G. K., Rahman, A., and Binder, B. M. (2012). Auxin and ethylene: collaborators or competitors? Trends Plant Sci. 17, 181-195. doi: 10.1016/j.tplants.2012.02.001

Nacry, P., Canivenc, G., Muller, B., Azmi, A., Van Onckelen, H., Rossignol, M., et al. (2005). A role for auxin redistribution in the responses of the root system architecture to phosphate starvation in Arabidopsis. Plant Physiol. 138, 2061-2074. doi: 10.1104/pp.105.060061

Nag, S., Saha, K., and Choudhuri, M. A. (2001). Role of auxin and polyamines in adventitious root formation in relation to changes in compounds involved in rooting. J. Plant Growth Regul. 20, 182-194. doi: 10.1007/s003440010016

Naija, S., Elloumi, N., Jbir, N., Ammar, S., and Kevers, C. (2008). Anatomical and biochemical changes during adventitious rooting of apple rootstocks MM 106 cultured in vitro. C. R. Biol. 331, 518-525. doi: 10.1016/j.crvi.2008.04.002

Negi, S., Ivanchenko, M. G., and Muday, G. K. (2008). Ethylene regulates lateral root formation and auxin transport in Arabidopsis thaliana. Plant J. 55, 175-187. doi: 10.1111/j.1365-313X.2008.03495.x

Negi, S., Sukumar, P., Liu, X., Cohen, J. D., and Muday, G. K. (2010). Genetic dissection of the role of ethylene in regulating auxin-dependent lateral and adventitious root formation in tomato. Plant J. 61, 3-15. doi: 10.1111/j.1365-313X.2009.04027.x

Nibau, C., Gibbs, D. J., and Coates, J. C. (2008). Branching out in new directions: the control of root architecture by lateral root formation. New Phytol. 179, 595-614. doi: 10.1111/j.1469-8137.2008.02472.x

Niu, S., Li, Z., Yuan, H., Fang, P., Chen, X., and Li, W. (2013). Proper gibberellin localization in vascular tissue is required to regulate adventitious root development in tobacco. J. Exp. Bot. 64, 3411-3424. doi: 10.1093/jxb/ert186

Ochoa, I. E., Blair, M. W., and Lynch, J. P. (2006). QTL analysis of adventitious root formation in common bean under contrasting phosphorus availability. Crop Sci. 46, 1609-1621. doi: 10.2135/cropsci2005.12-0446

O’Donnell, P. J., Calvert, C., Atzorn, R., Wasternack, C., Leyser, O. H. M., and Bowles, D. J. (1996). Ethylene as a signal mediating the wound response of tomato plants. Science 274, 1914-1917. doi: 10.1126/science.274.5294.1914

Okushima, Y., Fukaki, H., Onoda, M., Theologis, A., and Tasaka, M. (2007). ARF7 and ARF19 regulate lateral root formation via direct activation of LBD/ASL genes in Arabidopsis. Plant Cell 19, 118-130. doi: 10.1105/tpc.106.047761

Osmont, K. S., Sibout, R., and Hardtke, C. S. (2007). "Hidden branches: developments in root system architecture," in Annual Review of Plant Biology, (Palo Alto, CA: Annual Reviews), 93-113.

Overvoorde, P., Fukaki, H., and Beeckman, T. (2010). Auxin control of root development. Cold Spring Harb. Perspect. Biol. 2:a001537. doi: 10.1101/cshperspect.a001537

Pagnussat, G. C., Lanteri, M. L., and Lamattina, L. (2003). Nitric oxide and cyclic GMP are messengers in the indole acetic acid-induced adventitious rooting process. Plant Physiol. 132, 1241-1248. doi: 10.1104/pp.103.022228

Pagnussat, G. C., Lanteri, M. L., Lombardo, M. C., and Lamattina, L. (2004). Nitric oxide mediates the indole acetic acid induction activation of a mitogen-activated protein kinase cascade involved in adventitious root development. Plant Physiol. 135, 279-286. doi: 10.1104/pp.103.038554

Pan, R. C., Wang, J. X., and Tian, X. S. (2002). Influence of ethylene on adventitious root formation in mung bean hypocotyl cuttings. Plant Growth Regul. 36, 135139. doi: 10.1023/A:1015051725089

Péret, B., De Rybel, B., Casimiro, I., Benkova, E., Swarup, R., Laplaze, L., et al. (2009a). Arabidopsis lateral root development: an emerging story. Trends Plant Sci. 14, 399-408. doi: 10.1016/j.tplants.2009.05.002

Péret, B., Larrieu, A., and Bennett, M. (2009b). Lateral root emergence: a difficult birth. J. Exp. Bot. 60, 3637-3643. doi: 10.1093/jxb/erp232

Péret, B., Li, G. W., Zhao, J., Band, L. R., Voss, U., Postaire, O., et al. (2012). Auxin regulates aquaporin function to facilitate lateral root emergence. Nat. Cell Biol. 14,991-998. doi: 10.1038/ncb2573 
Péret, B., Middleton, A. M., French, A. P., Larrieu, A., Bishopp, A., Njo, M. F., et al. (2013). Sequential induction of auxin efflux and influx carriers regulates lateral root emergence. Mol. Syst. Biol. 9:699. doi: 10.1038/msb.2013.43

Pérez-Torres, C. A., López-Bucio, J., Cruz-Ramírez, A., Ibarra-Laclette, E., Dharmasiri, S., Estelle, M., etal. (2008). Phosphate availability alters lateral root development in Arabidopsis by modulating auxin sensitivity via a mechanism involving the TIR1 auxin receptor. Plant Cell 20, 3258-3272. doi: 10.1105/tpc.108.058719

Perrot-Rechenmann, C. (2010). Cellular responses to auxin: division versus expansion. Cold Spring Harb. Perspect. Biol. 2:a001446. doi: 10.1101/cshperspect.a001446

Petersson, S. V., Johansson, A. I., Kowalczyk, M., Makoveychuk, A., Wang, J. Y., Moritz, T., et al. (2009). An auxin gradient and maximum in the Arabidopsis root apex shown by high-resolution cell-specific analysis of IAA distribution and synthesis. Plant Cell 21, 1659-1668. doi: 10.1105/tpc.109.066480

Petricka, J. J., Winter, C. M., and Benfey, P. N. (2012). "Control of Arabidopsis roo development," in Annual Review of Plant Biology, Vol. 63, ed. S. S. Merchant (Palo Alto, CA: Annual Reviews), 563-590.

Pop, T. I., Pamfil, D., and Bellini, C. (2011). Auxin control in the formation of adventitious roots. Not. Bot. Horti Agrobot. Cluj Napoca 39, 307-316.

Przemeck, G. K., Mattsson, J., Hardtke, C. S., Sung, Z. R., and Berleth, T. (1996). Studies on the role of the Arabidopsis gene MONOPTEROS in vascular development and plant cell axialization. Planta 200, 229-237. doi: 10.1007/BF00208313

Ragonezi, C., Klimaszewska, K., Castro, M. R., Lima, M., De Oliveira, P., and Zavattieri, M. A. (2010). Adventitious rooting of conifers: influence of physical and chemical factors. Trees 24, 975-992. doi: 10.1007/s00468-010-0488-8

Rasmussen, A., Heugebaert, T., Matthys, C., Van Deun, R., Boyer, F. D., Goormachtig, S., et al. (2013). A fluorescent alternative to the synthetic strigolactone GR24. Mol. Plant 6, 100-112. doi: 10.1093/mp/sss110

Rasmussen, A., Mason, M. G., De Cuyper, C., Brewer, P. B., Herold, S., Agusti, J. et al. (2012). Strigolactones suppress adventitious rooting in Arabidopsis and pea. Plant Physiol. 158, 1976-1987. doi: 10.1104/pp.111.187104

Raya-Gonzalez, J., Pelagio-Flores, R., and Lopez-Bucio, J. (2012). The jasmonate receptor COI1 plays a role in jasmonate-induced lateral root formation and latera root positioning in Arabidopsis thaliana. J. Plant Physiol. 169, 1348-1358. doi: 10.1016/j.jplph.2012.05.002

Reed, R. C., Brady, S. R., and Muday, G. K. (1998). Inhibition of auxin movement from the shoot into the root inhibits lateral root development in Arabidopsis. Plant Physiol. 118, 1369-1378. doi: 10.1104/pp.118.4.1369

Richter, G. L., Monshausen, G. B., Krol, A., and Gilroy, S. (2009). Mechanical stimuli modulate lateral root organogenesis. Plant Physiol. 151, 1855-1866. doi: $10.1104 /$ pp. 109.142448

Riov, J., and Yang, S. F. (1989). Ethylene and auxin-ethylene interaction in adventitious root formation in mung bean (Vigna radiata) cuttings. J. Plant Growth Regul. 8, 131-141. doi: 10.1007/BF02025280

Robinson, D. (1994). The responses of plants to non-uniform supplies of nutrients. New Phytol. 127, 635-674. doi: 10.1111/j.1469-8137.1994.tb02969.x

Roycewicz, P., and Malamy, J. E. (2012). Dissecting the effects of nitrate, sucrose and osmotic potential on Arabidopsis root and shoot system growth in laboratory assays. Philos. Trans. R. Soc. Lond. B Biol. Sci. 367, 1489-1500. doi: 10.1098/rstb.2011.0230

Rubio, V., Bustos, R., Irigoyen, M. L., Cardona-Lòpez, X., Rojas-Triana, M., and Paz-Ares, J. (2009). Plant hormones and nutrient signaling. Plant Mol. Biol. 69, 361-373. doi: 10.1007/s11103-008-9380-y

Ruyter-Spira, C., Kohlen, W., Charnikhova, T., Van Zeijl, A., Van Bezouwen, L., De Ruijter, N., et al. (2011). Physiological effects of the synthetic strigolactone analog GR24 on root system architecture in Arabidopsis: another belowground role for strigolactones? Plant Physiol. 155, 721-734. doi: 10.1104/pp.110. 166645

Růžička, K., Ljung, K., Vanneste, S., Podhorská, R., Beeckman, T., Friml, J., et al. (2007). Ethylene regulates root growth through effects on auxin biosynthesis and transport-dependent auxin distribution. Plant Cell 19, 2197-2212. doi: 10.1105/tpc.107.052126

Růžička, K., Šimášková, M., Duclercq, J., Petrášek, J., Zažímalová, E., Simon, S., et al. (2009). Cytokinin regulates root meristem activity via modulation of the polar auxin transport. Proc. Natl. Acad. Sci. U.S.A. 106, 4284-4289. doi: 10.1073/pnas.0900060106
Rymen, B., and Sugimoto, K. (2012). Tuning growth to the environmental demands. Curr. Opin. Plant Biol. 15, 683-690. doi: 10.1016/j.pbi.2012.07.005

Sabatini, S., Beis, D., Wolkenfelt, H., Murfett, J., Guilfoyle, T., Malamy, J., et al. (1999). An auxin-dependent distal organizer of pattern and polarity in the Arabidopsis root. Cell 99, 463-472. doi: 10.1016/S0092-8674(00)81535-4

Sabatini, S., Heidstra, R., Wildwater, M., and Scheres, B. (2003). SCARECROW is involved in positioning the stem cell niche in the Arabidopsis root meristem. Genes Dev. 17, 354-358. doi: 10.1101/gad.252503

Sauter, M. (2013). Root responses to flooding. Curr. Opin. Plant Biol. 16, 282-286. doi: 10.1016/j.pbi.2013.03.013

Scheres, B., Benfey, P., and Dolan, L. (2002). Root development. Arabidopsis Book 1:e0101. doi: 10.1199/tab.0101

Scheres, B., Wolkenfelt, H., Willemsen, V., Terlouw, M., Lawson, E., Dean, C., et al. (1994). Embryonic origin of the Arabidopsis primary root and root meristem initials. Development 120, 2475-2487.

Schlicht, M., Ludwig-Müller, J., Burbach, C., Volkmann, D., and Baluska, F. (2013). Indole-3-butyric acid induces lateral root formation via peroxisomederived indole-3-acetic acid and nitric oxide. New Phytol. 200, 473-482. doi: 10.1111/nph.12377

Shkolnik-Inbar, D., and Bar-Zvi, D. (2010). ABI4 mediates abscisic acid and cytokinin inhibition of lateral root formation by reducing polar auxin transport in Arabidopsis. Plant Cell 22, 3560-3573. doi: 10.1105/tpc.110.074641

Sibout, R., Sukumar, P., Hettiarachchi, C., Holm, M., Muday, G. K., and Hardtke, C. S. (2006). Opposite root growth phenotypes of hy5 versus hy5 hyh mutants correlate with increased constitutive auxin signaling. PLoS Genet. 2:e202. doi: 10.1371/journal.pgen.0020202

Signora, L., De Smet, I., Foyer, C. H., and Zhang, H. M. (2001). ABA plays a central role in mediating them regulatory effects of nitrate on root branching in Arabidopsis. Plant J. 28, 655-662. doi: 10.1046/j.1365-313x.2001.01185.x

Simontacchi, M., Garcia-Mata, C., Bartoli, C. G., Santa-Maria, G. E., and Lamattina, L. (2013). Nitric oxide as a key component in hormone-regulated processes. Plant Cell Rep. 32, 853-866. doi: 10.1007/s00299-013-1434-1

Smith, D. L., and Fedoroff, N. V. (1995). LRP1, a gene expressed in lateral and adventitious root primordia of Arabidopsis. Plant Cell 7, 735-745. doi: 10.1105/tpc.7.6.735

Smith, S., and De Smet, I. (2012). Root system architecture: Insights from Arabidopsis and cereal crops. Philos. Trans. R. Soc. Lond. B Biol. Sci. 367, 1441-1452. doi: $10.1098 /$ rstb.2011.0234

Sorin, C., Bussell, J. D., Camus, I., Ljung, K., Kowalczyk, M., Geiss, G., et al. (2005). Auxin and light control of adventitious rooting in Arabidopsis require ARGONAUTE1. Plant Cell 17, 1343-1359. doi: 10.1105/tpc.105.031625

Sorin, C., Negroni, L., Balliau, T., Corti, H., Jacquemot, M. P., Davanture, M., et al. (2006). Proteomic analysis of different mutant genotypes of Arabidopsis led to the identification of 11 proteins correlating with adventitious root development. Plant Physiol. 140, 349-364. doi: 10.1104/pp.105.067868

Sreenivasulu, N., Harshavardhan, V. T., Govind, G., Seiler, C., and Kohli, A. (2012). Contrapuntal role of ABA: does it mediate stress tolerance or plant growth retardation under long-term drought stress? Gene 506, 265-273. doi: 10.1016/j.gene.2012.06.076

Stahl, Y., and Simon, R. (2012). Peptides and receptors controlling root development. Philos. Trans. R. Soc. Lond. B Biol. Sci. 5, 1453-1460. doi: 10.1098/rstb.2011.0235 Staswick, P. E., Serban, B., Rowe, M., Tiryaki, I., Maldonado, M. T., Maldonado, M. C., et al. (2005). Characterization of an Arabidopsis enzyme family that conjugates amino acids to indole-3-acetic acid. Plant Cell 17, 616-627. doi: $10.1105 /$ tpc. 104.026690

Steffens, B., Wang, J., and Sauter, M. (2006). Interactions between ethylene, gibberellin and abscisic acid regulate emergence and growth rate of adventitious roots in deepwater rice. Planta 223, 604-612. doi: 10.1007/s00425-0050111-1

Stepanova, A. N., Yun, J., Likhacheva, A. V., and Alonso, J. M. (2007). Multilevel interactions between ethylene and auxin in Arabidopsis roots. Plant Cell 19, 21692185. doi: 10.1105/tpc.107.052068

Strader, L. C., Chen, G. L., and Bartel, B. (2010). Ethylene directs auxin to control root cell expansion. Plant J. 64, 874-884. doi: 10.1111/j.1365-313X.2010.0 4373.x

Sukumar, P., Maloney, G. S., and Muday, G. K. (2013). Localized induction of the ABCB19 auxin transporter enhances adventitious root formation in Arabidopsis. Plant Physiol. 162, 1392-1405. doi: 10.1104/pp.113.217174 
Swarup, K., Benkova, E., Swarup, R., Casimiro, I., Peret, B., Yang, Y., et al. (2008). The auxin influx carrier LAX3 promotes lateral root emergence. Nat. Cell Biol. 10, 946-954. doi: 10.1038/ncb1754

Swarup, R., Perry, P., Hagenbeek, D., Van Der Straeten, D., Beemster, G. T., Sandberg, G., et al. (2007). Ethylene upregulates auxin biosynthesis in Arabidopsis seedlings to enhance inhibition of root cell elongation. Plant Cell 19, 2186-2196. doi: 10.1105/tpc.107.052100

Tian, H., Jia, Y., Niu, T., Yu, Q., and Ding, Z. (2014). The key players of the primary root growth and development also function in lateral roots in Arabidopsis. Plant Cell Rep. 33, 745-753. doi: 10.1007/s00299-014-1575-x

Ubeda-Tomás, S., Beemster, G. T. S., and Bennett, M. J. (2012). Hormonal regulation of root growth: integrating local activities into global behaviour. Trends Plant Sci. 17, 326-331. doi: 10.1016/j.tplants.2012.02.002

Ubeda-Tomás, S., Federici, F., Casimiro, I., Beemster, G. T. S., Bhalerao, R., Swarup, K., et al. (2009). Gibberellin signaling in the endodermis controls Arabidopsis root meristem size. Curr. Biol. 19, 1194-1199. doi: 10.1016/j.cub.2009.06.023

Vandenbussche, F., and Van Der Straeten, D. (2007). One for all and all for one: cross-talk of multiple signals controlling the plant phenotype. J. Plant Growth Regul. 26, 178-187. doi: 10.1007/s00344-007-9001-z

Vandenbussche, F., Verbelen, J. P., and Van Der Straeten, D. (2005). Of light and length: regulation of hypocotyl growth in Arabidopsis. Bioessays 27, 275-284. doi: 10.1002/bies.20199

Vanneste, S., De Rybel, B., Beemster, G. T., Ljung, K., De Smet, I., Van Isterdael, G., et al. (2005). Cell cycle progression in the pericycle is not sufficient for SOLITARY ROOT/IAA14-mediated lateral root initiation in Arabidopsis thaliana. Plant Cell 17, 3035-3050. doi: 10.1105/tpc.105.035493

Van Norman, J. M., Xuan, W., Beeckman, T., and Benfey, P. (2013). To branch or not to branch: the role of pre-patterning in lateral root formation. Development 140 4301-4310. doi: 10.1242/dev.090548

Vartanian, N., Marcotte, L., and Ciraudat, J. (1994). Drought rhizogenesis in Arabidopsis thaliana differential responses of hormonal mutants. Plant Physiol. 104, 761-767.

Verstraeten, I., Beeckman, T., and Geelen, D. (2013). "Adventitious root induction in Arabidopsis thaliana as a model for in vitro root organogenesis," in Plant Organogenesis: Methods and Protocols, ed. I. De Smet (New York: Humana Press, Springer Science, and Business Media).

Vidoz, M. L., Loreti, E., Mensuali, A., Alpi, A., and Perata, P. (2010). Hormonal interplay during adventitious root formation in flooded tomato plants. Plant J. 63, 551-562. doi: 10.1111/j.1365-313X.2010.04262.x

Visser, E. J. W., Cohen, J. D., Barendse, G. W. M., Blom, C. W. P. M., and Voesenek, L. A. C. J. (1996a). An ethylene-mediated increase in sensitivity to auxin induces adventitious root formation in flooded Rumex palustris Sm. Plant Physiol. 112, 1687-1692. doi: 10.1104/pp.112.4.1687

Visser, E. J. W., Bogemann, G. M., Blom, C., and Voesenek, L. (1996b). Ethylene accumulation in waterlogged Rumex plants promotes formation of adventitious roots. J. Exp. Bot. 47, 403-410. doi: 10.1093/jxb/47.3.403

Voesenek, L., Banga, M., Rijnders, J., Visser, E. J. W., and Blom, C. (1996). Hormone sensitivity and plant adaptations to flooding. Folia Geobot. Phytotax. 31, 47-56. doi: 10.1007/BF02803993

Walk, T. C., Jaramillo, R., and Lynch, J. P. (2006). Architectural tradeoffs between adventitious and basal roots for phosphorus acquisition. Plant Soil 279, 347-366. doi: 10.1007/s11104-005-0389-6

Wample, R. L., and Reid, D. M. (1976). Role of ethylene in adventitious root formation in flooded sunflower. Plant Physiol. 57, 98. doi: 10.1111/j.1399 3054.1979.tb01691.x

Wample, R. L., and Reid, D. M. (1979). Role of endogenous auxins and ethylene in the formation of adventitious roots and hypocotyl hypertrophy in flooded sunflower plants (Helianthus annuus). Physiol. Plant. 45, 219-226. doi: 10.1111/j.1399-3054.1979.tb01691.x
Wang, H., Qi, Q., Schorr, P., Cutler, A. J., Crosby, W. L., and Fowke, L. C. (1998). ICK1, a cyclin-dependent protein kinase inhibitor from Arabidopsis thaliana interacts with both $\mathrm{Cdc} 2 \mathrm{a}$ and $\mathrm{CycD} 3$, and its expression is induced by abscisic acid. Plant J. 15, 501-510. doi: 10.1046/j.1365-313X.1998. 00231.x

Wang, H., Xiao, W. D., Niu, Y. F., Jin, C. W., Chai, R. S., Tang, C. X., et al. (2013). Nitric oxide enhances development of lateral roots in tomato (Solanum lycopersicum L.) under elevated carbon dioxide. Planta 237, 137-144. doi: 10.1007/s00425-0121763-2

Welander, M., Geier, T., Smolka, A., Ahlman, A., Fan, J., and Zhu, L. H. (2014), Origin, timing and gene expression profile of adventitious rooting in Arabidopsis hypocotyls and stems. Am. J. Bot. 101, 255-266. doi: 10.3732/ajb. 1300258

Williamson, L. C., Ribrioux, S. P. C. P., Fitter, A. H., and Leyser, O. H. M. (2001). Phosphate availability regulates root system architecture in Arabidopsis. Plant Physiol. 126, 875-882. doi: 10.1104/pp.126.2.875

Xu, W. F., Jia, L. G., Shi, W. M., Liang, J. S., Zhou, F., Li, Q. F., et al. (2013). Abscisic acid accumulation modulates auxin transport in the root tip to enhance proton secretion for maintaining root growth under moderate water stress. New Phytol. 197, 139-150. doi: 10.1111/nph.12004

Yadav, S. R., Bishopp, A., and Helariutta, Y. (2010). Plant development: early events in lateral root initiation. Curr. Biol. 20, R843-R845. doi: 10.1016/j.cub.2010.09.010

Yoneyama, K., Xie, X., Kim, H. I., Kisugi, T., Nomura, T., Sekimoto, H., et al. (2012). How do nitrogen and phosphorus deficiencies affect strigolactone production and exudation? Planta 235, 1197-1207. doi: 10.1007/s00425-011-1568-8

Yue, K., and Beeckman, T. (2014). Cell-to-cell communication during lateral root development. Mol. Plant 7, 758-760. doi: 10.1093/mp/ssu012

Zhang, H. M., Jennings, A., Barlow, P. M., and Forde, B. G. (1999). Dual pathways for regulation of root branching by nitrate. Proc. Natl. Acad. Sci. U.S.A. 96, 6529-6534. doi: 10.1073/pnas.96.11.6529

Zhang, W., Swarup, R., Bennett, M., Schaller, G. E., and Kiever, J. J. (2013). Cytokinin induces cell divisions in the quiescent center of the Arabidopsis root apical meristem. Curr. Biol. 23, 1979-1989. doi: 10.1016/j.cub.2013. 08.008

Zhang, Z., Li, Q., Li, Z., Staswick, P. E., Wang, M., Zhu, Y., et al. (2007). Dual regulation of GH3.5 in salicylic acid and auxin signaling during Arabidopsis Pseudomonas syringae interaction. Plant Physiol. 145, 450-464. doi: 10.1104/pp.107.106021

Zolla, G., Heimer, Y. M., and Barak, S. (2010). Mild salinity stimulates a stressinduced morphogenic response in Arabidopsis thaliana roots. J. Exp. Bot. 61, 211-224. doi: 10.1093/jxb/erp290

Conflict of Interest Statement: The authors declare that the research was conducted in the absence of any commercial or financial relationships that could be construed as a potential conflict of interest.

Received: 10 May 2014; accepted: 06 September 2014; published online: 29 September 2014.

Citation: Verstraeten I, Schotte S and Geelen D (2014) Hypocotyl adventitious root organogenesis differs from lateral root development. Front. Plant Sci. 5:495. doi: 10.3389/fpls.2014.00495

This article was submitted to Plant Genetics and Genomics, a section of the journal Frontiers in Plant Science.

Copyright (c) 2014 Verstraeten, Schotte and Geelen. This is an open-access article distributed under the terms of the Creative Commons Attribution License (CC BY). The use, distribution or reproduction in other forums is permitted, provided the original author(s) or licensor are credited and that the original publication in this journal is cited, in accordance with accepted academic practice. No use, distribution or reproduction is permitted which does not comply with these terms. 